\title{
Señas de identidad judías y cristianas en la cuentística medieval: algunos ejemplos hispánicos*
}

\author{
Amparo Alba \\ Carlos Sainz de la Maza** \\ Universidad Complutense de Madrid
}

En este artículo los autores analizan la función del cuento como elemento literario de afirmación de la identidad cultural, judía o cristiana, en el mundo hispánico medieval. A modo de ilustración, se presenta un corpus de relatos tomados de obras medievales judías y en fuentes cristianas y que contienen elementos relevantes para el análisis.

Palabras clave: Cuentística medieval; literatura hebrea; marcas de identidad; judíos y cristianos; reinos hispánicos.

Jewish and Christian Identities as Depicted in Medieval Short Stories: Some Spanish EXEMPLES.- In this article the authors analyze the role of the tale as a literary factor for the assertion of Jewish and Christian cultural identity in late Medieval Iberia. They offer, as an example, a corpus of short stories taken from a range of Jewish and Christian written sources containing elements relevant to the analysis.

Keywords: Medieval Tales; Hebrew Literature; Marks of Identity; Jews and Christians; Iberia.

* Al final de este trabajo incluimos las referencias bibliográficas de las fuentes utilizadas, que citaremos desde ahora abreviadamente de acuerdo con el siguiente sistema de siglas: Antigüedades (Antigüedades judías); Cantigas (Las Cantigas de Santa María); Castigos (Castigos del Rey don Sancho IV); CrAlfX (Crónica de Don Alfonso X); DCler (Disciplina Clericalis); DDM(Declaración de los Diez Mandamientos); Esopete/Fábulas coletas (Sección tomada de DCler incorporada al Esopete ystoriado); EspLeg (Espéculo de los Legos); ExABC (Libro de los Exenplos por ABC); EXM (The Exempla of the Rabbis, ed. Gaster); GRom (Gesta Romanorum); LCMP (Libro de Confesión de Medina de Pomar); LegAu (Legenda Aurea); Lucanor (El Conde Lucanor); MDM (Midrás de los Diez Mandamientos); Milagros (Los Milagros de Nuestra Señora); MTanh. (Midrás Tanjuma); Recull (Recull d'exemples $i$ miracles ordenat per alfabet); ShMa (Sefer ha-Ma'asiyot); Š̌ (Sefer Ša'ašu 'im) TB (Talmud Babilónico); VYeh (La Vara de Yehudá); Zifar (Libro del cavallero Zifar).

**aalba@filol.ucm.es, csmaza@filol.ucm.es 
La presencia judía en la Península durante la Edad Media puede ser considerada como un fenómeno de etnias en contacto: los judíos forman una de las minorías monoteístas toleradas tanto en al-Ándalus (con los mozárabes cristianos) como en los reinos cristianos peninsulares (con los mudéjares musulmanes). Con el término «etnia» designamos a todo grupo socialmente organizado con una Historia común y unos rasgos definitorios ligados al desarrollo de esta; consecuencia y, enseguida, factor determinante de la interacción con otras etnias es el desarrollo de un conjunto de rasgos de índole diversa -la «identidad»- que permiten a los miembros del grupo reconocerse como pertenecientes al mismo y que, a la vez, abren una vía para la admisión como «conversos» de elementos exteriores a la comunidad ${ }^{1}$.

Aunque se percibe como dada, inmutable desde los orígenes, la identidad es una construcción social, que se adapta a las variaciones del contexto histórico del grupo étnico ${ }^{2}$. En este se produce un proceso doble de auto-definición y de identificación del Otro, que se ligan al establecimiento de una frontera étnica más o menos flexible, a la vez que claramente perceptible, y a un proceso de «invención de la Tradición» que da cuenta del existir del grupo como despliegue progresivo de un supuesto e indiscutido ser originario de aquel.

El grupo expresa su identidad étnica (manifestación de su adscripción consciente a ese ser ancestral comunitario) mediante una serie de elementos seleccionados entre los que constituyen su herencia cultural ${ }^{3}$. Tales elementos pueden ser tanto señales (lenguaje, vestido, modos de vida) como orientaciones de valores fundamentales ${ }^{4}$; el conjunto simboliza lo distintivo del grupo, digamos, en nuestro caso, lo judío (yahadut), y su continuidad histórica ${ }^{5}$.

\footnotetext{
${ }^{1}$ Nuestro enfoque es, así, similar al de W. W. IsaJiw, «Definition and Dimensions of Ethnicity: A Theoretical Framework», en Challenges of Measuring an Ethnic World: Science, Politics, and Reality (Washington, 1993), págs. 407-427; cf. también la formulación de S. STERn, Jewish Identity in Early Rabbinic Writings (Leiden-New YorkKöln 1994), pág. xiv, n. 2.

2 J. M. LIEU, Christian Identity in the Jewish and Graeco-Roman World (Oxford 2004), págs. 13-14. Sobre la formación de la identidad étnica judía y su cristalización en formas fuertemente refractarias a tal pauta adaptativa es imprescindible STERN, Jewish Identity.

${ }^{3}$ J. J. Pujadas, Etnicidad. Identidad cultural de los pueblos (Madrid 1993), pág. 44.

${ }^{4}$ F. BARTH, «Introducción», en Los grupos étnicos y sus fronteras, ed. F. BARTH (México 1976), págs. 9-49: 15.

${ }^{5}$ Pujadas, Etnicidad, págs. 63-64. Como señala Stern, Jewish Identity, pág. 10, yahadut, la 'judeidad', es un hápax tomado de Est.R. 7,11.
} 
La interpretación autorizada y la gestión de esa identidad colectiva corresponden, en gran medida, a las élites del grupo étnico. En el caso de las tres comunidades religiosas hispano-medievales, resulta relevante aplicar el concepto de «comunidad textual» ${ }^{6}$ a la hora de estudiar la formación de sus respectivas identidades: el grupo étnico es el resultado de la confluencia dinámica entre un texto escrito con valor normativo (una Ley divina, en este caso) y la experiencia social organizativa concreta, forzosamente adaptada en cada momento a las circunstancias históricas ${ }^{7}$. La identidad étnica se desarrolla sólo como consecuencia de la interacción social. Por eso, para su estudio, es clave el concepto de frontera étnica, expresada mediante un conjunto sistemático de reglas que canalizan la interacción con otros grupos y definen, en consecuencia, los estatus permitidos y prohibidos para los miembros de la comunidad ${ }^{8}$.

Al hablar de una identidad judía restringimos el campo de aplicación de la expresión a las comunidades judías de la Diáspora medieval occidental, expresión destacada del Judaísmo Clásico: una cultura que hereda el exclusivismo del antiguo Israel, así como una posición de dependencia política ahora agravada por la dispersión y, especialmente en los dominios cristianos, por la tensa relación genética entre la religión de la minoría judía y la del grupo social dominante", que lleva a los miembros de éste a elaborar y asignar públicamente una identidad judía negativa, potencialmente discriminatoria. En el caso cristiano, en concreto, se percibe al judío como al Otro por antonomasia ${ }^{10}$.

\footnotetext{
${ }^{6}$ Se definen las «textual communities» como «micro societies organized around the common understanding of a script»; cf. В. Sтоск, Listening for the Text. On the Uses of the Past (Baltimore \& London 1990), pág. 23.

${ }^{7}$ En relación con el Judaísmo y el Cristianismo, cf; Sтоск, Listening, págs. 149-158; Lieu, Christian Identity, pág. 24.

${ }^{8}$ BARTH, «Introducción», pág. 15; Lieu, Christian Identity, págs. 98-99 y 314-315, y, sobre todo, STERN, Jewish Identity, págs. 135-138 y 197-198, matizando el trabajo seminal de BARTH.
}

${ }^{9}$ R. DRAÏ, «Identité juive et identité chrétienne», en Identité juive, identité humaine (París 1995), págs. 187-222: 187 y 198-199.

${ }^{10}$ Contra la trivialización de J. M. Pedrosa, «El antisemitismo en la cultura popular española», en El antisemitismo en España (Cuenca 2007), págs. 31-55: 32, que cuenta al Judío como uno más de los varios otros construidos por la cultura cristiana occidental del Medioevo. También para J. Cohen, Living Letters of the Law. Ideas of the Jew in Medieval Christianity (Berkeley-Los Angeles-London 1999), en la baja Edad Media la excepcionalidad judía se diluye por su asimilación a la herejía a cuenta de la fidelidad a la 
Como es sabido, esta identidad judía «clásica» ", surge de la Tradición elaborada en el periodo que va de la re-construcción doctrinal del inicio del Segundo Templo a la fijación escrita del Talmud babilónico, devenido así texto canónico. Punto de partida de la misma es, naturalmente, la afirmación monoteísta. La consiguiente elección divina de Israel como auxiliar en el cumplimiento del ideal mesiánico como culminación y fin de la Historia, será la base para desarrollar una fuerte conciencia de pertenencia biológica e histórica nacional judía y una necesidad de impermeabilización que proteja a la comunidad de los contaminantes externos. Como forma más efectiva de lograrlo, lo judío se expresa de modo preferente no a través de creencias, sino de las ceremonias del culto y los ritos, más precisos que aquellas y reproducibles ad infinitum en su literalidad.

La referencia constante de esta identidad es el conjunto de textos que constituye la Tradición: la Torá, ante todo, y especialmente los preceptos que contiene, aunque en la realidad cotidiana resulte prioritaria la interpretación rabínica de la Ley mosaica, especialmente la halajá contenida en el Talmud babilónico. Como complemento, a veces casi canónico, una serie de obras exegéticas tardoantiguas y medievales, como, por ejemplo, el Mišné Torá de Maimónides. Ser o no ser judío depende, así, del estricto cumplimiento de esa preceptiva ${ }^{12}$.

En las condiciones de tolerancia pactada, nunca exenta de hostilidad emocional mutua, en que se desarrolla la vida judía de la Diáspora occidental, y de modo más acusado en los momentos de crisis como los experimentados, intermitente pero ininterrumpidamente, a partir más o menos de 1250 , se subraya deliberadamente la existencia de la frontera étnica dibujada por dichos preceptos rabínicos: la identidad judía se expresa, así, como mecanismo de resistencia del grupo frente a la presión externa del autoproclamado verus Israel cristiano ${ }^{13}$, y, a la vez, como fuerza coer-

Ley Oral de las comunidades contemporáneas; pero esta «segunda otredad» se superpone, sin anularla, a la original, vinculada a su citada relación genética con el cristianismo.

${ }^{11}$ STERn, Jewish Identity, passim y, particularmente, págs. 199-223 y 247-259; W. A. Irwin, y H. A. Frankfort, El pensamiento pre-filosófico, 2. Los hebreos (México 1968), pág. 142; DRAÏ, «Identité», págs. 193-194 y 196.

${ }^{12}$ Insiste en ello STERn, Jewish Identity, págs. 79-80. Así, «reading [the Scripture] is an endowing of principles with values for life situations. The link between reading and behavior is direct» de forma que la identidad se liga «[to] a subjectively perceived and intertextually supported rightness of conduct» (Sтоск, Listening, pág. 152).

${ }^{13}$ DrAÏ «Identité», págs. 200-202; LIEU, Christian Identity, pág. 101. 
citiva que intenta reprimir toda tendencia centrífuga en la comunidad. El rechazo de lo no judío (que, subrayémoslo, no implica aislamiento, sino interacción) se expresa, por ejemplo, a través de episodios bien conocidos que afectan a esferas muy diversas de la vida socio-cultural. La crítica pietista de los estudios de «filosofía griega» durante el siglo XIII ${ }^{14}$, las reiteradas acusaciones de «epicureísmo» lanzadas contra estudiosos y cortesanos judíos de las centurias siguientes ${ }^{15}$, o la mutilación infligida a la judía castellana amancebada con un musulmán en tiempos de la regencia de don Juan Manuel (1321) ${ }^{16}$, son buen ejemplo de esta actitud ${ }^{17}$.

\section{UN MATERIAL NARRATIVO COMPARTIDO}

Todo grupo étnico despliega su propio abanico de realizaciones culturales. Estas pueden ser en parte compartidas con otros grupos étnicos, y en parte pueden formalizarse como elementos integrantes de la identidad étnica.

Entre esos productos culturales se halla la cuentística, que en el caso judío se remonta a tiempos bíblicos y que, posteriormente, se aprovechó ampliamente, con fines didáctico-religiosos, en el corpus talmúdico y mi-

${ }^{14}$ Cf., por ejemplo, B. Septimus, Hispano-Jewish Culture in Transition (Cambridge MA-London 1982), págs. 61-74.

${ }^{15}$ Tales acusaciones asocian, de modo no siempre justo, la cultura filosófica moderna de parte de las élites judías peninsulares con el ambiguo estatus que a ciertos miembros de la misma les otorga su posición y privilegios cortesanos, emanados, evidentemente, del poder cristiano; un estatus que refleja el fenómeno de su adscripción a un «grupo de interés» (PujadAs, Etnicidad, pág. 23) sólo parcialmente coincidente con su grupo étnico originario.

${ }^{16}$ Cf. J. CASTaÑo, «Viudas al límite: vidas judías en la Castilla medieval», en El judaísmo, uno y diverso, ed. U. MAĆ́AS y R. IzQUIERDo (Cuenca 2005), págs. 194-201; en un contexto más general, D. NIRENBERG, «Love between Muslim and Jew in Medieval Spain: a Triangular Affair», en Jews, Muslims, and Christians in and Around the Crown of Aragon. Essays in Honour of Professor Elena Lourie, ed. H. J. HAMEs (Leiden-Boston, 2004), págs. 127-156, esp. 135-136. Recoge algún caso de relación entre judía y cristiano M. J. FuENTE, Identidad y convivencia. Musulmanas y judías en la España medieval (Madrid 2010), pág. 126. Recuérdese que Ber 58a identifica las relaciones sexuales con gentiles con el bestialismo.

${ }^{17}$ Otro campo de exhibición de la identidad judía es el de la competencia con la otra minoría, la mudéjar, en los reinos cristianos; cf., por ejemplo, J. SADAN, «Identity and Inimitability: Contexts of Inter-Religious Polemics and Solidarity in Medieval Spain, in the Light of Two Passages by Mose Ibn Ezra and Ya'aqov Ben Elazar», Israel Oriental Studies 14 (1994), págs. 325-348; D. NIRENBERG, Comunidades de violencia: la persecución de las minorías en la Edad Media (Barcelona 2001), págs. 237-283. 
drásico. Las más tardías colecciones de exempla son una novedad medieval y contaron con una nutrida representación en hebreo y, en menor escala, en romance, entre los judíos hispanos ${ }^{18}$.

Es evidente que, dada la orientación didáctica y pastoral de buena parte de los cuentos, estos funcionaron como factores de afirmación de la identidad judía en sus distintas manifestaciones teológicas, morales y rituales, como enseñanza doctrinal orientada a lo que podríamos llamar los fieles comunes. Sin embargo, no va a ser esa exhibición o recordatorio de rasgos identitarios nuestro principal objeto de estudio; como, en principio, tampoco vamos a ocuparnos del bien nutrido corpus narrativo con el que los cristianos se auto-confirmaban la identidad casi demoniaca popularmente asignada a los judíos, de la que tanto partido, por otra parte, supieron sacar los predicadores bajomedievales ${ }^{19}$.

Nos interesa, en principio, un grupo de relatos distinto y no necesariamente vinculado a la expresión de la identidad judía o cristiana. Lo forman aquellos cuentos que aparecen a la vez en colecciones medievales de exempla tanto judías como hispano-cristianas, en nuestro caso concreto, castellanas, aunque una cala en otras recopilaciones peninsulares lingüísticamente diversas daría resultados igualmente fructíferos ${ }^{20}$.

Estos cuentos compartidos por ambas tradiciones pueden, en algún caso, derivar en su versión cristiana de fuentes judías; baste recordar la enorme difusión de la Disciplina clericalis por toda Europa. Pero hay que hacer hincapié en la dificultad de establecer filiaciones de este tipo, dada la amplitud del alcance que tiene la difusión tradicional de los motivos narrativos que funcionan como constituyentes temático-estructurales del texto. De modo que no vamos a centrarnos en problemas de filiación, que no habría casi nunca forma de dilucidar, y sí, en cambio, en el examen de la medida en que esos cuentos presentan marcas que sirvan para expresar literariamente la identidad del grupo étnico, judío o cristiano, que los

\footnotetext{
${ }^{18}$ Cf. A. Alba y Á. Navarro, «La transmisión del cuento judío a Occidente», Estudios Mirandeses 25 (2005), págs. 7-22.

${ }^{19}$ En ese campo de la cultura general resulta cierta la enfática afirmación de DrAİ: «la culture, littéraire et musicale, de l'Occident deviendra un champ pestilentiel pour l'identitè juive» («Identité», pág. 201). Culminación bien conocida de esta forma de asignación negativa de identidad es el libro III del Fortalitium fidei (ca. 1458) del franciscano Fray Alonso de Espina, obra latina vinculada por su planteamiento y circunstancias de composición a la primera gran crisis anticonversa de la Corona de Castilla.

${ }^{20}$ Incluimos infra, a modo de recordatorio, alguna referencia al Recull catalán.
} 
recibe y reproduce oralmente o por escrito. Cada comunidad, de hecho, aprovecha cada cuento de un modo distinto en función del contexto literario -género de la obra, vínculos sociorreligiosos del autor, etc.- en que lo reproduce. Ese contexto, conviene aclararlo, es, en casi todos los casos, el de la cultura escrita; los textos se someten a la mediación de la élite letrada a pesar del carácter folclórico de muchos de sus temas y motivos. Entrarían, pues, potencialmente, en el conjunto de mecanismos de perpetuación étnica del grupo gestionados por el poder ${ }^{21}$.

El corpus de textos cristianos es, deliberadamente, romance casi en su totalidad, dado que representa el tipo de planteamientos que efectivamente se difunde entre el común, más o menos letrado, de la población peninsular. Hay, desde luego, especialmente agrupados bajo el epígrafe Iudaeus, muchos testimonios latinos, conservados en ejemplarios ligados a la actividad pastoral o lectora de los clérigos profesionales (Scala Celi, GRom, etc); pero resulta dificultoso establecer la difusión de dichas obras en el ámbito hispano, aunque sí puede rastrearse el conocimiento puntual de distintas versiones de muchos de tales exempla, lógicamente difundidos de forma oral y, desde luego, en romance, a través de la predicación mendicante ${ }^{22}$.

Teniendo en cuenta todos estos factores, hemos elaborado la siguiente tipología de material narrativo común a ambas tradiciones:

\section{Cuentos con expresión de identidad judía o cristiana:}

1. Cambio de personaje introduce cambio de identidad.

2. Cambio de personaje conlleva la anulación de la marca de identidad judía.

3. Cambio de personaje conlleva el cambio de un elemento que introduce cambio de identidad.

${ }^{21}$ Como se verá, no siempre se hallan dotados de marcas que ayuden a dicha perpetuación. Para una aproximación similar a la nuestra en el ámbito cultural asquenazí, cf. J. DAN, «Rabbi Judah the Pious and Caesarius of Heisterbach. Common Motifs in their Stories», en Studies in Aggadah and Folk-Literature [= Scripta Hierosolymitana 22], eds. J. Heinemann \& D. Noy (Jerusalem 1971), págs. 19-27.

${ }^{22} \mathrm{M}^{\mathrm{a}}$ R. LIDA DE MALKIEL, «Tres notas sobre don Juan Manuel», en Estudios de literatura española y comparada (Buenos Aires 1966), págs. 92-103; tablas de textos paralelos, EspLeg 1951, págs. 483-522. Conviene recordar que la oralidad en la recepción no establece, en principio, vínculos con la tradición oral folclórica. 
4. Mismos personajes pero cambio de un elemento que introduce cambio de identidad.

II. Cuentos sin marcas de identidad:

1. Relatos sin expresión directa de identidad; esta se asocia, en todo caso, con comentarios o moralizaciones añadidos en la versión cristiana.

2. Relatos sin ningún tipo de expresión de identidad.

III. Cuentos que reflejan la identidad asignada por el grupo étnico contrario:

1. La identidad cristiana según los judíos.

2. La identidad judía según los cristianos.

A partir de esta clasificación, presentaremos un breve corpus de relatos con elementos relevantes para nuestro análisis ${ }^{23}$. Estos se hallan presentes, además de en las fuentes rabínicas tradicionales (Talmud y midrašim) ${ }^{24}$, en un variado conjunto de obras medievales judías. Nuestras fuentes han sido, en este caso, las siguientes:

Midrás de los Diez Mandamientos (MDM): Probablemente la más antigua colección de cuentos (ca. siglos VIII-X), compuesta con el objetivo de transmitir los valores del judaísmo de forma amena; los cuentos pretenden ser una ilustración de los Diez Mandamientos, y de ahí su título. Su versión castellana, la Declaración de los Diez Mandamientos (DDM, de la primera mitad del siglo XV, se liga a la necesidad de perpetuar la identidad judía en el ambiente posterior a las conversiones masivas entre ca. 1391 a 1414.

Sefer ha-ma 'asiyot ('Libro de cuentos', ShMa): También conocido por el título de Hibbur yafé me-ha-yešu 'á ('Libro precioso de salvación'), es una colección compuesta por R. Nissim de Kairuán a mediados del siglo XI, para

\footnotetext{
${ }^{23}$ La muestra de relatos sobre la que hemos estructurado nuestro corpus no es exhaustiva y se halla abierta a ulteriores ampliaciones que pueden aportar tanto nuevos testimonios como matices o modificaciones importantes a la taxonomía de indicios identitarios que aquí se proponen. Por no poner más que un par de ejemplos, podrían ofrecer posibilidades en este terreno el cuento de Los tres amigos (que aparece en el Pirqué de Rabbí Eliezer, DCler, Barlaam y Josafat, etc.) o el de La serpiente desagradecida (Midrás Tanjuma, EXM, DCler, GRom, etc.)

${ }^{24}$ Con un par de añadidos, de mayor antigüedad, procedentes de la Biblia y de Antigüedades (ca. 90 d. C.).
} 
uso de la comunidad judía como alternativa al entretenimiento ofrecido por la cultura árabe.

Exempla de los rabinos (EXM): Nombre dado por Moses Gaster a una copiosa colección de historias ejemplares protagonizadas en su mayor parte por rabinos y derivadas de la Tradición anterior al medievo; puede datarse entre los siglos XIII y XIV.

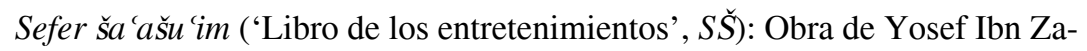
barra, compuesta en torno a 1190 en el Aragón recientemente reconquistado, es una miscelánea organizada según el modelo árabe de la macama. Los cuentos se vinculan a la tradición oriental de entretenimiento.

Šebet Yehudá ('La vara de Yehudá', VYeh): A pesar de tratarse de una obra historiográfica, la crónica miscelánea completada por Šelomó Ibn Verga después de 1506 incluye diverso material narrativo y legendario.

Por otra parte, hemos tomado relatos de otros tantos tipos de fuentes cristianas. Ante todo, de colecciones de exempla propiamente dichas, cuya piedra angular en Occidente es, sin duda, la Disciplina Clericalis (DCler). La obra de Pedro Alfonso, verdadero prontuario gnómico y narrativo de ética práctica, de extraordinaria difusión medieval, incluso en lenguas vulgares, es un texto de adscripción doble, una especie de oleoducto cultural que, en la forma hoy conocida (posterior a 1106), hace vivir entre los cristianos un legado «pris 'à la sagesse orientale' à travers les textes arabes»" ${ }^{25}$, patrimonio literario que florece también en el ámbito de las letras judías con posterioridad a Pedro Alfonso. Curiosamente, la España cristiana letrada conoció la obra de un modo casi siempre indirecto. ${ }^{26}$

El Espéculo de los legos (EspLeg), el Recull d'exemples (Recull) catalán y el Libro de los exenplos por $A B C(E x A B C)$ son obras relacionadas con el universo de la predicación bajomedieval: la primera romancea, en el siglo XV, el Speculum laicorum de Odo de Cheritón (siglo XIII); la segunda lo hace, en la misma época, con un repertorio alfabético dominico compilado en el XIV; del mismo tipo, pero directamente compuesta en castellano, es la tercera, anterior a 1421.

${ }^{25}$ R. E. MARSAN, Itinéraire espagnol du conte médiéval (Lille 1973), vol. I, pág. 95.

${ }^{26}$ MARsAn, Itinéraire espagnol, vol. I, págs. 132-133. M ${ }^{\mathrm{a}}$ J. LACARRA, «Ecos de la Disciplina Clericalis en la tradición hispánica medieval» en M ${ }^{\mathrm{a}} \mathrm{J}$. LACARRA (coord.), Estudios sobre Pedro Alfonso de Huesca (Huesca 1996), págs. 275-289. 
Una orientación específica como propaganda devota de alcance general poseen las colecciones de milagros marianos y de los santos: Los $\mathrm{Mi}$ lagros de Nuestra Señora (Milagros), de Gonzalo de Berceo, las Cantigas de Santa María (Cantigas) patrocinadas por Alfonso X, y la Legenda Aurea (LegAu), del dominico Jacopo da Varazze, todas ellas compiladas -en castellano, gallegoportugués y latín, respectivamente- en distintos momentos del siglo XIII ${ }^{27}$.

La misma vocación propagandística, ahora aplicada con pericia técnica a la educación religiosa de los laicos, marca el carácter de los Castigos, un espejo de príncipes compuesto ca. 1290 para el futuro Fernando IV de Castilla, y de las guías para bien confesarse, que cuentan en el siglo XV con el ejemplo destacado del Libro de confesión de Medina de Pomar (LCMP).

Hay, sin embargo, otras colecciones concebidas como lectura amena y, a la vez, formativa para laicos y clérigos; es el caso de dos obras mayores del siglo XIV, El Conde Lucanor (Lucanor) y los Gesta Romanorum (GRom) ${ }^{28}$. $\mathrm{Al} \mathrm{mismo} \mathrm{tipo} \mathrm{de} \mathrm{público,} \mathrm{circunscrito} \mathrm{además} \mathrm{al} \mathrm{ambiente} \mathrm{de} \mathrm{regeneración}$ cortesana surgido en Castilla torno a María de Molina, se dirige el Libro del caballero Zifar (Zifar), un roman caballeresco peculiar de comienzos del XIV donde ejemplos y sentencias poseen un papel estructural clave ${ }^{29}$.

De la aplicación a este corpus de la tipología ya mencionada ${ }^{30}$ resulta el siguiente repertorio de relatos con versiones paralelas adaptadas, en escala muy variable, a los ámbitos judío y cristiano peninsulares en que se difunden:

${ }^{27}$ LegAu (el Flos Sanctorum de las versiones hispanas), aunque compuesto en Italia hacia 1260, se difundió por todo Occidente en la baja Edad Media.

${ }^{28}$ GRom no es una obra hispánica peninsular ni llegó a traducirse al romance, pero sí gozó de amplísima difusión en la Edad Media; sirva aquí como muestra de la eficacia de la moralización aneja al exemplum para otorgar a éste un papel -negativo- en la valoración identitaria del Otro.

${ }^{29}$ En el mismo ámbito se compuso la Crónica de don Alfonso X (CrAlfX), en la que, como es propio del género, no siempre puede deslindarse lo histórico de lo narrativo y legendario.

${ }^{30}$ La tipología nace, desde luego, del examen de los relatos que integran el corpus. Tenemos en cuenta ciertos aspectos de la trabajada clasificación propuesta por $\mathrm{T}$. AleXANDER, The Heart is a Mirror. The Sephardic Folktale (Detroit 2007), que no nos decidimos a adoptar tanto porque se centra en la cuentística oral contemporánea de Israel como por los problemas derivados de su decisión de agrupar categorías formales pertenecientes a distintos niveles hermenéuticos del análisis narrativo. 


\section{CUENTOS CON EXPRESIÓN DE IDENTIDAD JUDÍA O CRISTIANA ${ }^{31}$}

\section{Cambio de personaje introduce cambio de identidad:}

Compañero inesperado en el Paraíso: J-MTanh (n ${ }^{\circ} 41$ Introd.), ShMa, $M D M$ (rabino y carnicero), $D D M \mathrm{~V}^{32} / / \mathbf{X}-\operatorname{ExABC} 122$ (51) (ermitaño y Papa Gregorio), Lucanor 3 (ermitaño y Ricardo Corazón de León).

Gobernante aconsejado por un sabio: J-TB Git 56b, EXM 70 (Vespasiano, recién nombrado Emperador, y R. Yojanán) // X-ExABC 204 (133) (Tito, paralizado por la elección de su padre, y «Josefo, que escribió la guerra de Roma contra los judíos, físico muy sabio») ${ }^{33}$.

Injusticia aparente de las respectivas honras fúnebres de un rico y un justo: J-TJ Hag, MDM, ShMa 1 (hijo recaudador impuestos/estudioso de la Torá, referencia a las filacterias) // X-ExABC 105 (34) (buen religioso en el yermo), LCMP 35 (ídem), Espéculo 511 (ídem).

Los juicios de Dios son incomprensibles: J-ShMa 2; DDM X; Ma'asé R. Yehosúa b. Leví I, págs. 211-212 (R. Yehosú'a y Elías) // X-ExABC 230 (161) (hombre santo y ángel en forma de ermitaño), GRom 80 (ermitaño y ángel $)^{34}$.

2. Cambio de personaje conlleva la anulación de la marca de identidad judía:

Marido aconsejado por su mujer: J-TB Ber 10a, EXM 46 (R. Meír) // $\mathbf{X}-\operatorname{ExABC} 302$ (233) (Un rey).

${ }^{31} \mathbf{J}=$ referencias en fuentes judías; $\mathbf{X}=$ referencias en fuentes cristianas.

${ }^{32}$ Algacel toma de las «tradiciones israelitas» una versión en que una pastora es la compañera en el Paraíso (MARSAN, Itinéraire espagnol, vol. II, pág. 732). Hay también -como para otros cuentos- paralelos en la narrativa hasídica del siglo XIII; cf. I. G. Marcus, «Hierarchies, Religious Boundaries, and Jewish Spirituality in Medieval Germany», Jewish History 1 (1986), págs. 7-26: 19. Para otras referencias medievales, cf. AleXANDer, The Heart is a Mirror, págs. 271-272.

${ }^{33}$ La amplia difusión del tema en el mundo cristiano deriva de LegAu (cf. vol. I, págs. 284-285).

${ }^{34}$ Este tipo narrativo alcanzó una gran difusión en la tradición europea medieval y posterior, tanto judía como cristiana; aparece también en el Corán (Sura 18, 65-80). 
Lo que Dios dispone es lo que conviene: J-TB Ta'an 21a, TB Sanh 109a, ShMa 5, EXM 25 (Najum de Gimzo: gam zo le-tob, 'también esto es para bien') EXM 150 (R. Aquiba, «todo lo que Dios hace es para bien» // X-Lucanor 18 (Pero Meléndez de Valdés: «quebréme el pie, será para bien») ${ }^{35}$.

Hombre justo no es atacado por leones: J- Dn 6, MDM 7 (R. Meír acusado de adulterio, "Quien encubre sus pecados no prospera», $\operatorname{Pr} 28,13$ ); ShMa 25 (sin león) // X-ExABC 411 (359) (La tentación de San Pachón, «Todo el que se eleva será rebajado [...]», Lc 18:14); CrAlfX (Leyenda del infante D. Enrique en Túnez).

Estafador estafado ${ }^{36}$ : J-TB Yoma 83b (Kidor, lentejas en bigote), ShMa (contra fariseos, hipocresía religiosa; ilustra el precepto de lavarse las manos) ver SŠ 5, (novella de Jacob de Córdoba), EXM 123 (el malo come comida prohibida: son cristianos), DDM VIII // X-DCler 15, ExA$B C 163$ (92) (vieja aconseja, no hay marcas identitarias), GRom 118 (vieja ermitaña aconseja, moralización cristiana añadida).

Estafador estafado («La caña hueca»): J-TB Ned 25a, LeR 6,3; EXM 121a // X-Espéculo 459 (la víctima es un judío; se convierte) ${ }^{37}$.

El camino del Paraíso es el difícil: J-TB Er 53b, EXM 236 (con bendición final del personaje a los hijos de Israel) // X-DCler 18a («De semita») y $18 \mathrm{~b}$ («De vado») $)^{38}$, ExABC 414 (362-363) (sólo mención final de «más vale camino largo a Paraíso que corto al Infierno»).

La caridad intensiva nos gana el Paraíso: J-TB BB 11a, TJ Pea I, 1, EXM 101 (rey Monobaz [de Adiabena], que según Josefo, Antigüedades, II, 4, era converso al judaísmo) ${ }^{39} / / \mathbf{X}$-DCler 29, ExABC 145 (74), 395 (339) (hijo de consejero real sabio y rico).

${ }^{35}$ Algacel también recoge la figura del beduino que, en las desgracias, concluye: «quizá sea mejor» (MARSAN, Itinéraire espagnol, vol. I, págs. 223-226 y II, pág. 732).

${ }^{36}$ Se trata del cuento conocido como «Los diez cofres», uno de los tipos más populares del folclore universal, como indica H. Schwarzbaum, «International Folklore Motifs [II]», Sefarad 22 (1962), págs. 17-59 y 321-344: 31.

${ }^{37}$ La versión más conocida de este cuento se halla en el capítulo XLV del Quijote de 1615, donde se integra entre las muestras de sabiduría de Sancho Panza en su tiempo de gobierno en sus días de gobernador de Barataria.

${ }^{38}$ Para Schwarzbaum, «International Folklore Motifs [II]», pág. 37, puede que la fuente de Pedro Alfonso no fuera talmúdica, sino sapiencial: el Kitab 'adāb al-Falāsifa de Hunain ibn Ishāq, el Juaniçio de los occidentales.

${ }^{39}$ El tema de las ventajas de la caridad es frecuente en el folklore árabe y judío (cf. SchwarZbaum, «International Folklore Motifs [II]», pág. 333). 
Los dos juglares: J- Antigüedades, XII, 208 (El joven Hircano y Trifón, bufón del rey Tolomeo) // X-DCler 21 (juglares) ${ }^{40}$.

3. Cambio de personaje conlleva el cambio de un elemento que introduce cambio de identidad:

a. Un judio escucha una conversación entre diablos: J- EXM 29 (judío arruinado por un gentil [cristiano]; este será castigado y él obtendrá riquezas) // X-ExABC 92 (21) (el judío conoce así la intención deshonesta del obispo, evita que peque y, como premio, es bautizado); EspLeg 137 (ídem, con moralización cristiana añadida).

\section{Mismos personajes pero cambio de un elemento que introduce} cambio de identidad:

El medio amigo: J- EXM 360 (Cod. Gaster 184, Norte de África; mata oveja) // $\mathbf{X}_{1}-$ DCler. 1 (mata ternero, «vitulum»); Castigos c. 35, ExABC 18, EspLeg, Esopete (Fábulas coletas) («bezerro», etc.) // $\mathbf{X}_{2}$-Recull («porch»), Zifar, Lucanor 48 («puerco»).

\section{CUENTOS SIN MARCAS DE IDENTIDAD}

\section{Relatos sin expresión directa de identidad (esta se asocia, en todo caso, con comentarios o moralizaciones añadidos en la versión cristiana):}

El falso heredero: J- I Re 3:16-28 (el juicio de Salomón); Sک̌ 5 (dos hijos, un falso heredero; juzga un juez) // X-ExABC 174 (103) (tres hijos: el verdadero respeta al padre); GRom. 45 (cuatro hijos; en la moralización sí se marca la identidad ${ }^{41}$ ).

${ }^{40} \mathrm{El}$ mismo relato, probablemente transmitido a través de las versiones latinas de las Antigüedades de Josefo (Schwarzbaum, «International Folklore Motifs [II]», pág. 49), aparece en occidente protagonizado por Dante, con los Cane della Scala como anfitriones; el humanista Poggio Bracciolini lo recoge, a mediados del siglo xv, en su Liber Facetiarum bajo el epígrafe de «Eiusdem Poetae Faceta Responsio»; ver P. Bracciolini, Facezie, Intr. E. Garin, ed. M. Ciccuto (Milano 1994), $n^{\circ} 58$.

${ }^{41}$ Los tres bastardos son los paganos, judíos y heréticos; el hijo verdadero, «el buen cristiano». El segundo (el judío) «asaeteó verdaderamente al rey de reyes cuando los 
2. Relatos sin ningún tipo de expresión de identidad:

La maldad de la mujer supera a la del demonio: J-SŠ 12 (lavandera desaviene pareja y desencadena matanza en la ciudad) // X-Lucanor 42 (falsa beguina ${ }^{42}$ ); ExABC 0 (370) (vieja); EspLeg 463 (vieja).

\section{Cuentos QUE REFLEJAN LA IDENTIDAD ASIGNADA POR EL GRUPO ÉTNICO CONTRARIO}

\section{Identidad cristiana según los judios:}

EXM 213a (R. Hanina hechizado por los cristianos), EXM 36 (R. Eliezer y el discípulo de Jesús), VYeh 8 (cristiano asesino culpa a vecina judía), etc. ${ }^{43}$.

\section{Identidad judía según los cristianos:}

Cantigas 4, Milagros 16, ExABC 269 (judiezno quemado por su padre), Cantigas 6 (judío asesino), ExABC 91 (20) (profanación de crucifijo), ExABC 202 (131) (carácter engañoso de los judíos), Recull 353 (credulidad y estupidez judía), etc. ${ }^{44}$.

judíos decían: 'Venid, golpeémoslo en la lengua' mientras apagaban su sed con hiel mezclada con vinagre».

${ }^{42}$ El carácter específicamente cristiano del beguinaje permitiría también incluir la versión juanmanuelina de este enxiemplo entre los portadores de una marca indirecta de identidad. Sobre la inquina del autor a las beguinas, cf. LIDA, «Tres notas sobre Don Juan Manuel», págs. 101-102. MARSAN, Itinéraire espagnol, vol. II, págs. 673-674 indica que la historia es también muy popular en la cuentística árabe.

${ }^{43}$ La gama de enfoques es muy amplia: abarca desde la reformulación de los relatos cristianos de profanación sacrílega obra de judíos a los cuentos humorísticos en que un cristiano es objeto de burlas; la estudia, en el ámbito folclórico, AleXAnder, The Heart is a Mirror, págs. 169 y 427.

${ }^{44}$ Cf. sólo MARSAN, Itinéraire espagnol, vol. II, págs. 348ss. para otros casos ilustrativos del supuesto odio judío a los cristianos manifiesto en blasfemias y profanaciones de la Hostia, la Cruz, etc. Pero también vol. II, págs. 739-740, que recoge sendos relatos de Algacel en que los hombres justos que evitan la tentación de la carne son un monje cristiano y un asceta judío, señal de que la identidad asignada no es siempre y automáticamente negativa, y de que es función de las condiciones concretas de la interacción social en cada momento. 


\section{ANÁLISIS COMPARATIVO DE ALGUNOS TEXTOS}

Dada la amplitud del corpus disponible, nos limitaremos aquí a presentar algunos ejemplos incluidos en los dos primeros apartados de esta tipología ${ }^{45}$. El tercer apartado, donde se pierde la coincidencia de textos, abarca, sin embargo, cuentos que alcanzaron una enorme popularidad al reflejar la identidad, evidentemente negativa, asignada por el grupo étnico contrario, tanto por parte judía como, sobre todo, cristiana

\section{1) Cuentos con expresión de identidad judía o cristiana $^{46}$}

\section{Cambio de personaje introduce cambio de identidad}

b. Gobernante aconsejado por un sabio: J-TB Git 56b; EXM 70 (Vespasiano, recién nombrado Emperador, y R. Yojanán) // X-ExABC 204 (133) (Tito, paralizado por la elección de su padre, y «Josefo, que escribió la guerra de Roma contra los judíos, físico muy sabio»).

En la leyenda talmúdica la escena se desarrolla durante el sitio de Jerusalén por las fuerzas romanas dirigidas por el general Vespasiano; Rabbán Yojanán ben Zakay, patriarca de Jerusalén, consigue, mediante una estratagema, eludir el cerco de la ciudad y tener una audiencia con Vespasiano, al que pedirá permiso para fundar una escuela rabínica en Yabné cuando Jerusalén sea conquistada. En ese encuentro el rabino saluda a Vespasiano como emperador, anticipándose al nombramiento que tendrá lugar durante la audiencia. La elección de estos dos personajes es, desde el punto de vista de la identidad judía, muy importante; a Rabbán Yojanán ben Zakay, uno de los sabios más destacados de Jerusalén en aquel momento, se le debe la reconstrucción y organización de la vida judía tras la destrucción del Templo, con la elaboración de leyes que permitieron la adaptación del judaísmo a la nueva situación. Vespasiano, por su parte, es, según la tradición rabínica, el emperador que propició ese cambio al acceder a las peticiones de Rabbán Yojanán.

${ }^{45}$ El texto completo de los mismos textos menos conocidos o asequibles se transcribe como Apéndice, al final de nuestro trabajo.

${ }^{46}$ Las siglas alfanuméricas corresponden a las empleadas en el corpus recogido en el Apéndice. 
El cambio de protagonistas en el relato cristiano conlleva la reformulación identitaria del relato; el rabino es sustituido por Josefo (quien en el cap. 14 del libro III de la Guerra Judía se atribuye la predicción relativa a Vespasiano), personaje odiado por sus coetáneos judíos a raíz de su actuación en la guerra contra los romanos, y Vespasiano, por su hijo Tito, uno de los emperadores más odiados en la tradición rabínica, responsable de la destrucción y profanación del Templo. Curiosamente, ambos personajes son asumibles como representantes de la identidad cristiana: Josefo, cuyas obras y personalidad despertaron muy pronto la simpatía y el interés de círculos cristianos $^{47}$, y Tito, del que se dice en $\operatorname{ExABC} 68$ que «fue un noble emperador, e de tanta clemencia e piedat acerca de sus súbditos».

\section{2) Cambio de personaje conlleva la anulación de la marca de identidad judía}

c. Hombre justo no es atacado por leones: J- Dn 6, MDM 7 (R. Meír acusado de adulterio, "Quien encubre sus pecados no prospera», Pr 28:13); ShMa 25 (sin león) // X-ExABC 411 (359) (La tentación de San Pachón, «Todo el que se eleva será rebajado [...]», Lc 18:14); CrAlfX (Leyenda del infante D. Enrique en Túnez).

En este nuevo ejemplo de heroísmo moral rabínico, el protagonista judío, R. Meír, es objeto de abusos sexuales por parte de la mujer de un amigo suyo, en un episodio que recuerda al de las hijas de Lot. Aunque él propiamente no es culpable de adulterio, decide someterse a las autoridades religiosas para cumplir una condena, pues, según Pr 28:13, «Quien encubre sus pecados no prospera»; es condenado a morir devorado por leones, pero tras ser expuesto durante tres noches sucesivas a este castigo, los leones rehúsan matarlo. Se considera cumplida la sentencia cuando, por fin, un león le da un mordisco «del tamaño de una aceituna».

Los relatos castellanos que reproducen motivos semejantes son protagonizados por un monje y por el infante D. Enrique de Castilla, hermano de Alfonso X; en ellos, la sentencia de muerte no se puede ejecutar por la

\footnotetext{
${ }^{47}$ Gracias a los pasajes sobre Jesús contenidos en el libro XVIII de las Antigüedades Judías conocidos como Testimonium Flavianum; cf. Antigüedades, lib. XVIII, 3.3 y XX, 9.1. Sobre Josefo como sanador, cf. S. Kоттек, Medicine and Hygiene in the Works of Flavius Josephus (Leyden 1994), págs 191-195.
} 
inocencia de los protagonistas. Como R. Meír, también San Pachón busca voluntariamente castigarse por un pecado cuya inexistencia es puesta de relieve por la actitud de los leones; el episodio se integra en una serie que ensalza los valores ascéticos del estado monástico. D. Enrique, cuya condición de personaje turbulento queda patente en el texto cronístico, aparece, sin embargo, también como modelo de valor aristocrático capaz de imponer respeto al receloso rey de Túnez y sus cortesanos: su aventura con los leones, forzada por la envidia de aquellos, lo transforma en una especie de Daniel caballeresco y, evidentemente, cristiano ${ }^{48}$.

3) Cambio de personaje conlleva el cambio de un elemento que marca cambio de identidad

a. Un judío escucha una conversación entre diablos: J- EXM 29 (judío arruinado por un gentil [cristiano]; este será castigado y él obtendrá riquezas) // $\mathbf{X}$-ExABC 92 (21) (el judío conoce así la intención deshonesta del obispo, evita que peque y, como premio, es bautizado); EspLeg 137 (ídem, con moralización cristiana añadida).

El relato judío, buen ejemplo de ameno cuento ejemplar con elementos sobrenaturales, describe una conversación, con apuesta incluida, entre un judío y un gentil, probablemente cristiano (arameo) sobre la superioridad de la religión de cada uno. Los diversos personajes que aparecen en el camino testifican a favor de la religión del gentil, lo que produce la ruina y la desmoralización del judío. Al pernoctar en unas ruinas (lugar frecuentado por diablos en la tradición judía), es testigo de una conversación entre tres diablos que exponen sus logros: burlarse del judío declarando a favor de la religión del gentil, impedir el parto de la hija del césar y cegar una fuente; el judío es testigo de cómo se solucionarían los dos últimos problemas, lo que más tarde le permitirá recuperar su prosperidad inicial. Desde el punto de vista de la enseñanza moral derivada del cuento, se reafirma la superioridad de la religión judía, al ser la del gentil, finalmente castigado, avalada sólo por el diablo.

\footnotetext{
${ }^{48}$ La anécdota del infante y los leones, evocada en clave paródica por D. Juan Manuel, pudo haber dado origen al irónico enxienplo 9 de Lucanor. Sobre las andanzas de D. Enrique, que llegó a ser senador romano y a compartir la suerte adversa de los Staufen en su enfrentamiento con el Papado y Charles de Valois, cf. S. Runciman, Vísperas sicilianas. Una historia del mundo mediterráneo a finales del siglo XIII (Madrid 1979), págs. 102 y 107-117, passim.
} 
Los dos relatos cristianos desarrollan el mismo esquema, pero la estructuración narrativa es más compleja en $E x A B C$. Hay un segundo personaje principal de corte histórico: Andrés, obispo de Fondi (Lazio); la anécdota narrativa transcurre en Roma, capital de la Cristiandad, en «un templo de un dios que llamaban Apolo», lugar natural en la adaptación cristiana de la mitología pagana para la aparición de demonios y espíritus malignos. El antagonismo inicial entre gentil y judío desaparece; el énfasis en la identidad viene dado a través de determinados elementos nuevos presentes en la anécdota de los diablos. Así, ExABC presenta un relato insertado en otro. El relato principal (derivado de los Diálogos de San Gregorio) corresponde al obispo Andrés, al judío y a los diablos que hablan en el templo. El insertado (tomado de las Vitae Patrum) ejemplifica cómo pudo ser esa conversación demoniaca que no llega a transcribirse en el relato principal; en ella se ilustra que la más diabólica de las acciones no es fomentar la violencia para provocar destrucciones y muertes, sino tentar a un hombre santo para que caiga en el pecado de la carne. El judío de la historia principal viene marcado desde el principio por su asociación con el signo cristiano por antonomasia: aunque no cree, se santigua. Los diablos reconocen en él esta señal; su exclamación: « ¡Vaso vacío, mas signado!», pone de relieve que la identidad cristiana es la única real; el bautismo (el llenado del «vaso») es, pues, la consecuencia lógica de la elección de este judío por la Providencia. Desde el punto de vista identitario cristiano, el bautismo eleva la categoría de la recompensa del personaje muy por encima de la del relato judío, donde se limitaba a la obtención de bienes materiales.

El relato de EspLeg narra la misma historia de una forma más condensada, prescindiendo del cuento insertado; añade, sin embargo, al final, una explicación didáctica que subraya la enseñanza moral y que refuerza la afirmación de identidad cristiana ligada al relato, enlazando a la vez con la tradición cristológica de lectura figurada del AT:

E de aquí es lo que es escripto a los IX capitulos de Ezechiel: Non matades al que vierédes que trae sobre sí la T [Ez 9:4]. E la T es una letra que es fecha a manera de cruz, en figura que la cruz del Sennor libra al ome e lo defiende [de] la muerte ${ }^{49}$.

\footnotetext{
${ }^{49}$ En Ez 9:3-4, Dios le dice «al hombre vestido de lino que tenía la cartera de escriba en la cintura» que marque con una taw la frente de los hombres que gimen y lloran por todas las prácticas abominables que se cometen en Jerusalén. En paleohebreo la taw tenía forma de cruz aspada. Denotaba la propiedad de ganados, esclavos y otros bienes y era usada como firma por quienes no sabían escribir (cf. Jb 31:35). Los marcados por
} 
Con los nuevos elementos presentes en los relatos cristianos la identidad judía del protagonista se diluye y reformula de acuerdo con el punto de vista, típicamente medieval, según el cual todo judío contemporáneo no es más que un cristiano en potencia ${ }^{50}$.

\section{4) Mismos personajes pero cambio de un elemento que introduce cambio de identidad}

a. El medio amigo: J- EXM 360 (Cod. Gaster 184) // $\mathbf{X}_{1}$ - DCler 1; Castigos c. 35, ExABC 18, EspLeg 49, Esopete / Fábulas coletas 1 // $\mathbf{X}_{2}$-Recull («porch»), Zifar, Lucanor 48 («puerco»).

El cuento del «medio amigo», muy popular en el folclore semíti$\mathrm{co}^{51}$, se encuentra asociado en las fuentes judías y cristianas que hemos examinado a otros dos relatos ampliamente difundidos: el del «amigo íntegro» y el de «los tres amigos». En este relato, un padre insta a su hijo a poner a prueba a sus amigos. El hijo ruega a estos que le ayuden a ocultar un saco manchado de sangre que, supuestamente, contiene el cuerpo de un hombre asesinado por él. Ante el rechazo de todos, acude a un «medio amigo» de su padre, quien le ayuda a enterrar el saco en su patio. En algunos relatos es el propio padre el que lleva el saco (EXM 360); en otros, es el hijo, ignorante de su verdadero contenido (Lucanor, Zifar); en otros, el hijo conoce el contenido (DCler, ExABC, EspLeg). El elemento afectado por el contexto identitario en que se difunde cada versión del cuento es el animal muerto que hay en el saco: la tradición judía, transmitida a Occidente por DCler, se refiere a un ternero (en la probable versión original árabe 'aŷal, o, si era hebrea, 'eguel); los textos cristianos se dividen en dos ramas: unos retoman el vitulum ('ternero') de Pedro Alfonso (Castigos, ExABC, EspLeg, Esopete, etc.) mientras que otros transforman el animal en un cerdo, «un puerco» ( $\mathrm{Zi}$ far, Lucanor, Recull). Esta variante, que dota al relato de una marca de

esta señal (como Caín en Gé 4:15) son propiedad del Señor, parte sagrada de la ofrenda sacrificial y, por ello, intocables.

${ }^{50}$ Sobre la raíz agustiniana de esta postura, cf. CoHEN, Living Letters, págs. 19-65.

${ }^{51}$ H. Schwarzbaum, «International Folklore Motifs in Petrus Alphonsi’s Disciplina Clericalis [I]», Sefarad 21 (1961), págs. 267-299: 285. 
identidad claramente cristiana, aunque no necesariamente antijudía ${ }^{52}$, tiene fuentes comunes con colecciones latinas de comienzos del siglo XIV (por ejemplo, GRom 129); en algún caso se subraya de forma casi caricaturesca, como en el Zifar, donde la broma culmina con una comida aparentemente canibalística en la que el hijo elogia el buen sabor de la supuesta carne humana (i.e., de la carne de cerdo). El cerdo perdura en la tradición oral (tipo 893 de Aarne-Thompson) y, de forma muy significativa, la tradición judeo-española en tierras del Islam lo sustituye por un cordero (EXM 360: Cod. Gaster 184, procedente del Norte de África; tradiciones orales de los judíos de Tetuán y Salónica ${ }^{53}$ ).

\section{Cuentos Sin MARCAS DE IDENTIDAD}

\section{1) No expresión directa de identidad; esta se asocia con comentarios o moralizaciones añadidos ${ }^{\text {s4 }}$}

a. Juicio de Salomón: J-1Re 3:16-28 (el juicio de Salomón); SŠ 5 (2 hijos, 1 falso heredero; juzga un juez) // X- ExABC 174 (103) (3 hijos: el hijo verdadero respeta al padre); GRom. 45 (4 hijos)

En $S \check{S}$ se cuenta la historia de un comerciante rico cuyo único hijo parte a ver mundo; el hijo de una sirvienta, al que el comerciante cuida como si fuera su auténtico hijo, pretende suplantar la identidad del verdadero tras la muerte del comerciante. Ambos jóvenes acuden ante un juez para

${ }^{52}$ Marsan, Itinéraire espagnol, vol. II, pág. 606; Mª J. Lacarra, «Ecos de la Disciplina clericalis en la tradición hispánica medieval», en Estudios sobre Pedro Alfonso de Huesca, ed. M. J. LACARRA (Huesca 1996), págs. 275-289: 282, encuentra lógico el cerdo en la tradición cristiana, como animal que se criaba para el abastecimiento familiar de carne. Lógica aparte, «pork is [...] the distinctive mark of the non-Jew» para el judaísmo rabínico desde la antigüedad (STERN, Jewish Identity, pág. 56, remitiendo a NmR 20, 21 y QoR 7, 11). El Zifar, por su parte, posee una orientación claramente antijudía; cf. F. J. HERNÁNDEZ, «Un punto de vista (ca. 1304) sobre la discriminación de los judíos», en Homenaje a Julio Caro Baroja (Madrid 1978) págs. 587-593; J. L. GIRÓN NEGRÓN, «La maldición del can: la polémica antijudía en el Libro del caballero Zifar», Bulletin of Hispanic Studies 78 (2001), págs. 275-295.

${ }^{53}$ LaCARra, «Ecos de la Disciplina Clericalis», págs. 281-282. Marsan, Itinéraire espagnol, vol. II, págs. 595-596 y 790, añade un ejemplo anterior procedente de Ibn Arabí de Murcia (m. 1240).

${ }^{54}$ No comentamos por extenso casos del tipo relatos sin ningún tipo de expresión de identidad. 
que dilucide su legitimidad; el fallo del juez recuerda el juicio de Salomón; mediante él, se reconoce al verdadero heredero.

El cuento reaparece en la tradición cristiana, con variantes en el número de hijos (tres en $E x A B C$, cuatro en GRom) y en la formulación del conflicto, sin incorporar ninguna marca de identidad; esta se hace presente en la moralización que añade GRom, en la que el hijo verdadero es «el buen cristiano» y sus contrincantes son los paganos, judíos y herejes; uno de estos, el judío, «asaeteó verdaderamente al rey de reyes cuando los judíos decían: 'Venid, golpeémoslo en la lengua' mientras apagaban su sed con hiel mezclada con vinagre».

\section{LAS MARCAS DE JUDEIDAD AL SERVICIO DE UNA IDENTIDAD NUEVA: LOS CONVERSOS}

Hasta aquí hemos manejado un concepto de la identidad judía como constelación de rasgos culturales que expresan la conciencia de pertenencia a una comunidad que, en su anclaje social, y como etnia no dominante y por su interterritorialidad, necesita marcar claramente una frontera. Ésta se expresaría, en un Estado moderno, mediante leyes que plasmaran la Tradición (valores, costumbres, cultura material...) de la comunidad; por el contrario, en la Edad Media, como ya mucho antes, se reguló a través de preceptos religiosos cuyo cumplimiento estricto ayudaba a la reducción del tiempo punitivo de la Diáspora con vistas al definitivo advenimiento mesiánico.

A partir de su dispersión por la cuenca mediterránea y Europa occidental, la población judía se convirtió en una etnia marcada negativamente. La presencia dominante e institucionalizada del Cristianismo (y, en una medida más variable, la del Islam en los países musulmanes) la condenó a ser vista a través de una lente identitaria deformante y a sufrir un cúmulo de presiones cada vez más intensas para su conversión ${ }^{55}$. Como es sabido, tales presiones se institucionalizan y se formalizan en numerosas controversias públicas y en obras literarias relacionadas con ellas; en el fondo de este proceso subyace un rechazo emocional radical, siempre dispuesto a salir a la luz si lo manipulan los agentes adecuados en circunstancias favorables.

\footnotetext{
${ }^{55}$ Estudia el proceso hasta 1300 CoHEN, Living Letters, retomando y desarrollando trabajos anteriores.
} 
Es evidente que tal manipulación existió y acabó haciendo crisis en la Península entre 1391 y 1414. Consecuencia de esa crisis es la brusca incorporación del nuevo grupo judeoconverso como sector diferenciado dentro de la sociedad cristiana «vieja». Los conversos, obligados a un salto identitario brutal que sólo se irá decantando con el paso del tiempo, acabarán, como grupo, ofreciendo un abanico muy amplio de grados de aculturación ${ }^{56}$. Durante este proceso ciertos aspectos de su comportamiento social pueden analizarse según los parámetros propios de una comunidad inmigrante ${ }^{57}$ : así, y más allá del visible deseo de ser plenamente aceptados en la sociedad cristiana peninsular, resultan muy perceptibles rasgos como la endogamia, la tendencia al desarrollo de actividades profesionales y económicas típicamente judías o el mantenimiento de una solidaridad de grupo que permite reacciones enérgicas y coordinadas en los cada vez más numerosos episodios de violencia provocados por los cristianos viejos. Esta resistencia a la asimilación pura y simple facilita, por su parte, la conservación parcial de la identidad judía como elemento constituyente de una nueva forma de identidad cristiana. Es, en este sentido, correcta la denominación de «cristianos nuevos». Sin embargo, la percepción cristianovieja de esa diferencia será reformulada interesada y maliciosamente, de forma que la identidad asignada a los judíos pasará, de estar basada en conductas erradas, a convertirse en una adscripción racial basada en esencias; a partir de ese momento, la élite cristiana hace suyo el secular (y, en muchos casos, vivo todavía hoy) punto de vista popular sobre los judíos. Tal asignación de identidad se aplicará a los conversos en los términos en los que se expresan, por ejemplo, los manifiestos de los rebeldes toledanos de 1449 y los de sus imitadores

${ }^{56}$ Abanico que va de la plena integración a la existencia secreta del judaizante resistente, y sobre cuya composición se ha entablado desde hace ya algunos años una polémica en la que ahora no resulta pertinente entrar. Para su planteamiento, cf. en principio B. Netanyahu, Los orígenes de la Inquisición en la España del siglo XV (Barcelona 1999) y B. Rosenstock, New Men: Conversos, Christian Theology, and Society in FifteenthCentury Castile (London 2002). Interesan, al respecto, las observaciones acerca de la energía judaizante liberada por las conversiones y su papel en la reformulación identitaria conversa que hace D. NIRENBERG, «Une société face à l'altérité. Juifs et Chrétiens dans la Péninsule Ibérique 1391-1449» Annales. Histoire, Sciences Sociales 62 (2007), págs. 755-790: 771-772.

${ }^{57}$ Pujadas, Etnicidad, pág. 24. Por su parte, Stern habla, en relación con la posición de los "'ame ha-Aretz», de la existencia de «grey areas» identitarias que desdibujan la dicotomía entre Israel y los gentiles y que incluyen -sería el caso de los conversos hispanosidentidades alternativas cuyos sujetos se percibirían a sí mismos a la vez como «emphatically Israel but simultaneously akin to the non-Jews» (Jewish Identity, págs. 126-127). 
posteriores de la misma centuria; y las consecuencias de tal fractura en el modo de percepción identitaria marcarán la vida social y cultural hispánica hasta, por lo menos, la llegada de la Ilustración.

En este contexto se escribe, o tal vez sólo se copia, la Declaración de los Diez Mandamientos, versión castellana del Midrás de los diez Mandamientos contenida en el Ms. 2015 de la Biblioteca de la Universidad de Salamanca ${ }^{58}$, códice de mediados del siglo XV procedente del Colegio de San Bartolomé de esa ciudad. El romanceamiento de $M D M$ apunta, por su lengua, al que sería el modo habitual de difusión de una cuentística que en hebreo resultaba ininteligible para la mayoría de la población judía peninsular. Ofrece una docena larga de ma'asiyot ilustrativos de los Mandamientos formulados en Ex 20 y ss., protagonizados por personajes de los que, en ocasiones, se nos dice que son «de los ebreos», orgullosos de formar parte del pueblo elegido y hasta didácticos a la hora de hacer profesión pública de su fe ${ }^{59}$.

Las raíces folclóricas de muchos de los relatos se reorientan así para colaborar al efecto de afirmación de las señas de identidad judías propio de la obra ${ }^{60}$; rasgo en el que abundan otros textos del mismo manuscrito, como el tratado para el examen de conciencia con vistas al Yom Kippur, el romanceamiento del libro de Ester, etc., incluidos en él por el compilador a partir de fuentes castellanas de diverso origen. La perspectiva cambia, sin embargo, radicalmente cuando se advierte que uno de estos textos, una ordenada selección de citas del Antiguo Testamento destinadas a probar la excelencia ancestral del pueblo judío, se aplica de modo explícito nada menos que a reivindicar el derecho de los conversos a ser respetados y honrados con cargos y beneficios en un plano de igualdad con los cristia-

${ }^{58} \mathrm{El}$ manuscrito fue editado, en tirada limitada y con importantes errores, por M. LAZAR, Sefer Teshubah: Book of Repentance; a Ladino Compendium of Jewish Law and Ethics (Culver City CA 1993); una edición más cuidada de la obra que nos interesa puede consultarse en A. Alba y C. SAINz de la MazA, «La declaración de los Diez Mandamientos en su versión judeoespañola», Bulletin Hispanique 103 (2001), págs. 369-402.

59 Alba y SaInz de la MAzA, «La declaración de los Diez Mandamientos», pág. 377; cf. Introducción, Introducción a Mandamientos 1 y 2 y Mandamientos 1-5 y 10a.

${ }^{60}$ Una parte de los cuentos reflejan un proceso de oicotipificación: en la versión castellana podemos citar, por ejemplo, el del hombre que santificaba el sábado ( $4^{\circ}$ Mandamiento, $D D M$ págs. 385-386) y el de la prueba de la adúltera gemela ( $7^{\circ}$ mandamiento, $D D M$ pág. 390$)$. Para un estudio del $M D M$ hebreo desde este punto de vista, cf. D. Noy, «General and Jewish Folktale Types in the Decalogue Midrash»(heb.), en Fourth World Congress of Jewish Studies: Papers II (Jerusalem 1968), págs. 313-315. 
nos «viejos»; y no sólo eso, sino que se consideran a sí mismos superiores incluso a estos, debido a la elección divina del linaje de Abraham del que descienden. La obrita, que expresa una postura frecuente entre los conversos con posterioridad a la crisis de 1449, cambia el valor de todo el códice en relación con el tema de la identidad ${ }^{61}$. Pues los textos originalmente emanados de la conciencia de identidad judía como signos inequívocos de la misma han de ponerse ahora al servicio de una peculiar reivindicación identitaria cristiana. Hay que tomar los cuentos de nuestra $D D M$, por tanto, como un dato más que puede ayudarnos a comprender el doble sentido de pertenencia: judío contenido en el global cristiano, y no negado por él, característico de la comunidad cristianonueva española (no de su minoría resistente de criptojudíos, ni de su otro grupito de cínicos al estilo de Pedro de la Caballería), a la que tan terribles pruebas le quedaban aún por pasar en el complejo tránsito hispánico desde el Medioevo a la Edad Moderna.

En la $D D M$, que selecciona una parte de los cuentos del $M D M$ hebreo, hay también notables coincidencias con relatos presentes en la tradición cristiana $^{62}$, siendo también perceptible el contraste entre las marcas de identidad de unos y otros. A modo de ejemplo elocuente incluimos entre los textos del Apéndice uno de los cuentos que ilustra el décimo mandamiento (el sabio y Elías), junto con su equivalente de $E x A B C^{63}$ (el santo y el ángel $)^{64}$.

${ }^{61}$ Edita el tratadito LAZAR, Sefer Teshubah, págs. 193-229, pero no coincide con nuestra interpretación del mismo.

${ }^{62} \mathrm{Cf}$. los relatos sobre el mozo judío que aplaca una tormenta en el mar invocando a su Dios (primer mandamiento), el justo que nunca juró (tercer mandamiento), o el carnicero como acompañante de un justo en el paraíso (quinto mandamiento; cf. supra, Corpus I, 1.a), así como el de Elías y el sabio (décimo mandamiento) que mencionamos a continuación. Para los textos y antecedentes de todos ellos, cf. DDM, passim.

${ }^{63}$ Cf. supra, Corpus I, 1.d: «Los juicios de Dios son incomprensibles».

${ }^{64}$ Una versión abreviada de este trabajo se expuso como ponencia en el Coloquio Internacional «Identidades judías en la Baja Edad Media», celebrado en 2007 en la Facultad de Filosofía y Letras de la Universidad de Granada. 


\section{Texto de los relatos comentados}

\section{I.1.b. Cambio de personaje introduce cambio de identidad: Gobernante aconsejado por un sabio}

\section{EXM 70}

Aba Sicara, jefe de los sicarios de Jerusalén, era sobrino de Rabbán Yojanán ben Zakay. Este le llamó en privado y le dijo: «¿Hasta cuándo vais a seguir matando al pueblo de hambre?» Le respondió: «¿Qué puedo hacer yo? Si digo algo, me matarán». Dijo R. Yojanán: «Busca el modo de que yo escape, a ver si puedo salvar algo». Le dijo: «Hazte el enfermo durante tres días y que digan que estás muerto. Lleva contigo algo hediondo y que te lleven tus discípulos en las angarillas - sólo tus discípulos, no sea que se den cuenta de que estás vivo, porque un vivo pesa menos que un muerto, y digan: ‘qué desgracia! un ser vivo que se lleva a sí mismo'».

Así lo hizo. Se pusieron bajo las angarillas R. Eliécer, por un lado, y Rabí Yehosúa por otro. Cuando llegaron a las puertas de la ciudad algunos quisieron traspasarlo con una lanza, pero dijeron los discípulos: «Van a decir que han clavado a Rabbán». Entonces dijeron que lo arrojaran (al otro lado), pero insistieron los discípulos: «Dirán que han arrojado a Rabbán». Así que abrieron la puerta y les dejaron salir.

Se presentó ante Vespasiano, y le saludó: «La paz sea contigo, rey, la paz sea contigo». Vespasiano le dijo: «Mereces la muerte dos veces: una, porque no soy rey y me has llamado rey, y otra, porque si fuera rey, ¿cómo no te has presentado antes ante mí?» Le respondió: «En cuanto a lo que dices, que no eres rey, (sí que lo eres, pues) si no fueras rey, Jerusalén no habría caído en tus manos, pues está escrito: Y el Líbano caerá por mano del poderoso [I Sam 10:34]; al decir «poderoso» sólo puede referirse a un rey, pues está escrito: $Y$ su soberano del seno de [la asamblea] saldrá [Je 30:21]. En cuanto a lo que dices de por qué no me he presentado antes ante ti, la razón es que los zelotas que hay entre nosotros no me han dejado. A lo que contestó Vespasiano: «Si hubiera una serpiente enroscada sobre un tarro de miel, ¿no habría que romper el tarro para librarse de la serpiente?» [Rabbán] se calló y no le respondió nada. R. Yosef [según otros R. Aqiba] le aplicó este versículo: Que hago volver atrás a los sabios y desvanezco su sabiduria [Is 4:25] Hubiera debido decirle: «mejor sería coger una pinza, sacar la serpiente y dejar el tarro». 
En ese momento llegó un mensajero imperial y le dijo: «Levanta, que el emperador ha muerto y los nobles de Roma te han nombrado emperador». Se había puesto una bota y se fue a poner la otra, pero no pudo calzársela. Intentó quitarse la otra, pero no se la pudo quitar. Le dijo [Rabbán Yojanán]: «No te preocupes, pues está escrito: Una buena nueva vigoriza los huesos [Pr 15:30]». Le preguntó: «¿Cómo se arregla?» Le dijo: «Que venga alguien a quien aborrezcas y pase ante ti, pues está escrito: Un espíritu abatido seca los huesos [Pr 17:22]».

Hizo eso y [el pie] entró. Le dijo: «Siendo tan sabio, ¿por qué te quedaste allí?» Le respondió: «Ya te lo he dicho». Le dijo [Vespasiano]: «Yo también te lo he dicho. Ahora tengo que irme y mandaré aquí a otro; pídeme lo que desees y te lo concederé». Le dijo: «Deseo que me des a Yabné y sus sabios, la familia de Rabbán Gamaliel y médicos para curar a R. Sadoq». R. Yosef [según otros R. Aqiba] le aplicó este versículo: Que hago volver atrás a los sabios y desvanezco su sabiduría [Is 44:25]. Debió decirle: «Déjalos por esta vez [a los judíos]», pero pensó que no le concedería tanto y no podría salvar nada.

\section{ExABC 204 (133)}

INFIRMITAS QUECUMQUE CONTRARIIS EST CURANDA: Cualquier la enfermedat para sanar / con melezina contraria la han de curar.

Leyemos que Tito, fijo de Vaspasiano, estava sobre Jerusalem que la tenía cercada, e oyó dezir cómo todos los senadores de Roma eligieran a Vaspasiano, su padre, por enperador. E tanto fue el gozo que ovo que a deshora se tollesció todos los mienbros e non pudo mandar alguno dellos. E Josepho, que escrivió la guerra de Roma contra los judíos, físico muy sabio, entendiendo la causa de la enfermedat preguntó si avía alguno en el mundo a quien mucho mal quisiesse Tito, e que aborresciesse oír su nonbre. E uno díxole que avía un ombre que llamavan Nicio, que aborrescía tanto que ninguno en su corte non le osava nonbrar. E este Josepho fizo venir aquel ombre, e un día mandó poner una mesa muy abastada de todos los manjares e mandó que estoviessen allí mancebos que serviessen de viandas e de vinos e mandóles secretamente que ninguno non feziesse cosa alguna que Tito mandasse; e todas las cosas assí aparejadas, fizo asentar aquel ombre a quien mucho desamava Tito a la mesa con toda onra, e mandó a los servidores que lo serviessen con tanta onra e reverencia e como a enperador. E mirándolo Tito así a aquel su henemigo, començósse a encender como fuego e mandó a sus servidores que lo matassen. E ninguno non queriendo obedescer su mandamiento, ante lo servían. E en tanto se encendió de la ira que todos los 
mienbros que tenía tollescidos recebieron sanidat. E veyendo él que por la vista de aquel su enemigo rescebiera sanidat, de allí adelante non le ovo por enemigo mas por fiel amigo.

\section{I.1.d. Cambio de personaje introduce cambio de identidad: Los juicios de Dios son incomprensibles.}

\section{DDM, X}

Era un sabio et toda vía cobdiçiava de andar con Elías el profeta. Et ayunó muchos ayunos et fazía muchas rogativas al sennor Dios, que le cunpliese su voluntad. Et el sennor Dios gela cunplió; et enbiólo a Elías. Et díxole Elías al sabidor en cómmo era enbiado del sennor Dios para él, que qué cosa era la que demandava. Et respondió el sabidor et dixo: «Sennor, la mi voluntad et la mi entinçión es de andar contigo». Et díxole Elías: «Pues lo has a voluntad plázeme, mas resçelo que no podrás andar comigo». Et dixo: «¿Por qué?». Et díxole: «Porque verás cosas que non las podrás sofrir». Et dixo: «Aunque non las pueda sofrir mi voluntad es de andar contigo». Et díxole Elías: «Pues lo has a voluntad a mí plaze d'ello». Et luego fueron la primera noche et durmieron en una casa de un menesteroso, que estava él et su muger et non tenían salvo una vaca. Et así como los vido el omne pobre levólos a su casa et dioles de comer et de bever, et les fizo mucha honra segunt ellos meresçían. Et levantóse Elías et tomó la vaca et matóla. Et así commo vido aquello el sabidor que andava con él dixo en su coraçón que no podía ser que aquel fuese Elías, que tal cosa fizo; que no podía ser que Elías matase cosa ajena, «demás seyendo de tal pobre commo este que nos fizo mucha honra». Et Elías, desque vido que el sabidor estava murmureando de lo que avía visto fazer a Elías, et díxole: «Sy me tienes de preguntarlo por qué lo fago no has más de andar comigo». Et ovo de callar el sabidor. Et luego fueron amos a dos a otro logar et fallaron ý un omne rico que estava labrando unas casas. Et commo los vido no se levantó a ellos nin los conbidó para su casa para comer nin para bever. Et a media noche levantóse Elías et dixo al sabidor: «Levántate, amigo». Et el sabidor levantóse et díxole Elías: «Tira del cabo de la cuerda». Et travó d'ella et Elías travó del otro cabo, et midieron las paredes et fizieron çiento et ochenta palaçios. Et en que vido el sabidor lo que fizo Elías maravillóse mucho et dixo en su coraçón: «¿Qué obra es esta que faze Elías? Al cuytado del pobre que nos llevó a su casa et nos dio de comer et de bever et nos fizo mucha honra matóle una vaca, que no tenía más; et este omne rico que no 
nos fizo honra ninguna, fízole tanto bien et labróle toda su obra en un punto». Et maravillóse mucho et calló; et fueron a otro logar que eran todos ricos, et así commo los vieron a Ellías et al sabidor non curaron d'ellos nin les mostraron buena cara nin los conbidaron. Et otro día de mananna madrugó Elías et dixo: «Por el sennor Dios et por su santa merçed, Él vos faga a todos cabeçeras d'este logar». Et fueron a otro logar que eran todos pobres, et así commo los vieron saliéronlos a resçebir de buena voluntad; con todo su menester et su mengua diéronles bien de comer et bien de bever. Et en la mananna madrugó Elías et dixo: «No vos dé el Sennor más de una cabeçera sobre vosotros». Et entonçe dixo el sabidor a Elías: «No puedo sofrir estos fechos que faze[s]; mi voluntat es que me digas todos estos fechos que has fecho». Et díxole Elías: «Sy voluntad has de lo saber no andes comigo más, mas pregunta lo que quieres que yo te lo diré». Et preguntó el sabidor a Elías: «¿Por qué mataste la vaca de aquel pobre que no tenía otro bien synon aquel et que nos fizo açás de solás?». Et díxole Elías: «Sepas que la noche que maté la vaca de aquel ome, esa noche avía de morir su muger, que la quería más que mill doblas. Et por eso me adelanté et maté su vaca por que fuese perdonada su muger et fuese una ánima por otra». Et preguntóle el sabidor et dixo [a] Elías: «El rico que era escaso et no nos fizo honra ninguna, ¿por qué le labraste su casa?». Et díxole Elías: «Sepas que si aquel onbre le dexara abrir los çimientos de aquella obra que quería faser, que fallara grant tesoro. Et por que non lo fallase adelantéme yo a labrarle la casa; mas aquella obra non le será firme». «Et aquellos ricos que no nos fizier[o]n honra ninguna, ¿por qué les diste bendiçión que fuesen todos cabeçeras?». Et díxole Elías: «Estruymiento les oré». «¿Et a los pobres que nos fizieron honra et les dexiste que no oviesen más de una cabeçera?». Et díxole Elías: «Sabe que todo logar onde no ay en él más de una cabeçera a la postre será bien poblado et terná pas». En ese punto dixo Elías al sabidor que non andoviese más con él et luego se partió d'él.

\section{$\operatorname{ExABC} 230(161)$}

Judicia Dei justa et abissus multa: Los juizios de Dios, justos e ascondidos, / por ombres del mundo non pueden ser sabidos.

Un santo ombre, padre viejo, rogó a Dios que le mostrasse de sus juizios, al qual un día aparesció el ángel en figura de hermitaño viejo e díxole: «Vamos visitar estos padres que están en el yermo e rescibamos la bendicion dellos».

E yéndosse venieron a una cueva e llamaron, e salió a ellos un viejo de santa vida e rescebiólos con alegría. E desque ovieron fecho oración lavóles los pies 
e púsoles mesa e dioles de comer, e reposaron ende aquella noche. E de mañana inbiólos con buena voluntad.

El ángel ascondidamente tomó el escodilla en que comía e levósela, e veyéndolo el monje, entre sí dixo: «¿Por qué feziera a este santo ombre esto, el qual nos rescebió con gozo? ¡Le furtó la escodilla!».

E yéndosse, enbió a su fijo en post dellos que le diessen la escodilla. El ángel le dixo: «Delante de nos va a quien la di; ven e tomarla has».

E yendo con ellos, el ánge[1] desde una altura derribólo e morió. E veyendo esto el monje, fue muy triste e ovo temor e pensó: «¿Qué cosa era esta? ¿E non abastava que furtó el escodilla, e agora mató al fijo?».

E dende a dos días venieron a una celda donde estava un hermitaño viejo con dos discípulos, e quando llamaron a la puerta, enbió el un discípulo a dezir: «¿Quién sodes, o qué demandades?». E dixieron: «Venimos de trabajar e querríamos aver bendición». E enbióles dezir que non convenia. E dixieron: «Pues rescebitnos esta noche que posemos aqui». E mandóles que se fuessen, que non podía ser, deziendo: «¿Por que andades vagabundos?».

E ellos començaron a suplicarle deziendo: «Ya es noche. Rescibitnos por que non nos coman aquí animalias». E a duro los rescebió. E rogaron les diesse un poco de lunbre, e non ge lo dio; e dende a poco rogaronle que les diesse un poco de agua. Estonce uno de los discípulos dioles un poco de pan e una poca de agua ascondidamente, e rogóles que non lo sopiesse el abbat. E en la mañana dixo el ángel: «Ruega al abbat que diga misa, ca le queremos ofrescer». E luego el abbat vino presto, e el ángel ofrecióle la escodilla que avía furtado. E veyendo esto el monje que iva con él, con gran saña díxole: «iAmigo, vete, que yo non quiero mas ir contigo! ¡Furtaste esta escodilla al santo ombre e matástele el fijo, e a este mald[i]to e malo, que non teme a Dios nin ha piedat de los ombres, diste la escodilla!».

E díxole el angel: «Tú bien sabes que rogaste a Dios que te mostrasse sus juizios, e yo soy enbiado a te los mostrar. Sabe que la escodilla que yo tomé al santo ombre non era bien ganada. E maté yo a su fijo porque la noche seguiente avía de matar a su padre. E di la escodilla que hera mal ganada a este malo para añadir a su dapnacion».

Lo qual dicho, el ángel desaparescio, e estonce conoció el monje que los juizios de Dios eran justos e verdaderos, ahunque algunos paresce son contra justicia. 
I.2.c. Cambio de personaje conlleva la anulación de la marca de identidad judía: Hombre justo no es atacado por leones

\section{MDM 7}

Cuentan que R. Meír iba a Jerusalén en las fiestas de peregrinación y se alojaba en casa de R. Yehudá el carnicero, que tenía una esposa bella y recatada, siempre atenta a honrar a R. Meír cuando iba a su casa. Al cabo de algún tiempo, esta mujer murió y R. Yehudá se casó de nuevo; dijo a su nueva esposa: «Cuando venga a verme R. Meír, hónralo mucho, hazlo entrar en casa, ofrécele comida y bebida y sírvesela hasta que acabe; luego, prepárale una buena cama con buenas sábanas para que descanse». Ella le dijo que así lo haría.

Cuando llegó el día de la peregrinación y R. Meír entró en Jerusalén, fue a casa de R. Yehudá. Dijo a la mujer: «Quiero ver a la esposa de R. Yehudá».

Ella le dijo: «Señor, mi marido me ha dicho que cuando venga aquí un erudito llamado R. Meír le honrara y le ofreciera comida y bebida. Así pues, aquí me tienes, dispuesta a honrarte más que su primera mujer». El le contestó: «No puedo entrar con el beneplácito de la mujer sino con el beneplácito del dueño de la casa». Salió fuera y se encontró con R. Yehudá, que le dijo: «Mi primera mujer murió». Entonces volvió R. Meír a casa de R. Yehudá. La mujer fue a prepararle comida y bebida, y la puso ante él; mientras él comía, ella permanecía de pie y le servía.

Era R. Meír un joven apuesto, y la mujer puso sus ojos en él; le emborrachó hasta tal punto que no podía distinguir entre su derecha y su izquierda; le hizo la cama y R. Meír, adormilado, se acostó en ella y se durmió con gran sopor. La mujer permaneció ante él, le quitó la ropa y se acostó con él hasta que amaneció, sin que él se diera cuenta ni al acostarse ella ni al levantarse [Gé 19:33-35], y durmió con ella toda la noche.

Por la mañana, se levantó R. Meír y fue a la escuela midrásica a rezar. Cuando regresó, ella preparó, muy afectuosa, comida y bebida para él. Mientras él comía y bebía, ella le servía y hablaba y se reía; R. Meír se dijo: «QQué atrevida es esta mujer!» y miraba al suelo, para no verla. Entonces ella le dijo: «¿Por qué no me miras? Has dormido toda la noche conmigo sin avergonzarte y ahora, ¿te avergüenzas de mí?». El exclamó: «¡Eso no es verdad!» «№ me crees? -dijo ella- ¿No hay tales marcas en tu cuerpo?»

Al punto se convenció R. Meír de que se había acostado con ella; con gran amargura en su corazón, se puso a gritar y a llorar diciendo: «¡Ay de mí, que he 
destruido la Torá que aprendí!, ¿qué remedio habrá ahora para mí?, ¿qué puedo hacer?; me presentaré ante el Presidente de la Academia y le expondré mi caso; aceptaré lo que me ordene».

Regresó a su casa y fue todo el camino gimiendo y llorando, se rasgó las vestiduras y se echó polvo a la cabeza. [Al verle] salieron todos sus vecinos y le dijeron: «¿Qué piensas hacer?» Les dijo: «Voy a presentarme ante el Presidente de la Academia que hay en Babilonia, y aceptaré cualquier sentencia que emita acerca de mí». Le dijeron: «Has pecado sin intención y no has cometido delito; el Santo, bendito sea, te perdonará; no lo proclames para que no se calumnie a tus hijos». Contestó: «Si os escucho a vosotros, el Santo, bendito sea, no perdonará nunca mis pecados, pues está escrito: Quien encubre sus pecados no prosperará» [Pr 28:13].

A continuación fue a ver al Presidente de la Academia de Babilonia, y se sentó ante él diciendo: «Presidente de la Academia [...] esto es lo que me ha ocurrido y por eso me he presentado ante ti; cualquier cosa que decretes, ya sea que muera o que sea devorado por bestias feroces, lo aceptaré». Le contestó: «Espera un poco a que examinemos tu caso».

Al día siguiente le dijo el Presidente de la Academia: «Hemos examinado tu causa y hemos decidido que seas devorado por fieras salvajes y por leones». Respondió R. Meír: «Acepto el juicio divino».

Y se dispuso a ejecutar lo que había ordenado el Presidente de la Academia. [Este] llamó a dos hombres fuertes de Israel y les dijo: «Llevad a este hombre al bosque, a un lugar en que lo puedan encontrar los leones, atadlo de pies y manos y dejadlo allí; vosotros permaneceréis encaramados en lo alto de un árbol observando lo que ocurre; si lo devoraran, traedme sus huesos para hacerle un gran funeral por haber aceptado la sentencia divina».

Lo llevaron al bosque, junto a un lugar por el que solían pasar leones, lo ataron de pies y manos y se quedaron allí, sobre un árbol para ver qué ocurría. A media noche vino un león, se paró junto a él, gruñó, le olfateó y se fue. A la mañana siguiente se presentaron ante el Presidente de la Academia y le dijeron: «El león no le hizo nada, salvo olfatearlo, y luego se marchó».

Les dijo: «Haced lo mismo una noche más».

Así lo hicieron. A media noche vino un león, se paró junto a él, gruñó, volvió la cabeza y se fue. A la mañana siguiente contaron lo ocurrido al Presidente de la Academia, quien les dijo: «Haced lo mismo una noche más, y si no le toca, traédmelo, y no se cumplirá en él la sentencia divina». 
Así lo hicieron. A media noche vino un león, se paró junto a él, gruñó, rugió, le dio una dentellada y le arrancó un poco de carne, del tamaño de una aceituna.

Cuando, a la mañana siguiente le contaron lo ocurrido al Presidente de la Academia, les dijo: «Si ya ha comido un poco de él, traédmelo».

Lo llevaron a su presencia, y ordenó a unos médicos que le curaran. Regresó R. Meír a su casa y oyó una voz celestial que decía: «R. Meír es merecedor de la vida futura».

\section{$\operatorname{ExABC} 411$ (359)}

Temptacio carnis valde afrigit Dei sanctos: De la carne la grand temptación / a los santos da aflición.

Un monje era mucho temptado de la cobdicia de la carne. E fue a un monje muy sancto que llamavan Pachón que avía sesenta años que estava en un monesterio e confessósele con muchas lágrimas aquella temptación.

E díxole el sancto ombre: «Fijo, non te turbes por esta razón, ca esto non te viene por tu culpa, mas por inbidia del diablo; ca véyesme tan viejo comoquier que con la ayuda de Dios so diligente de la salud de mi ánima, empero fasta agora sienpre sofrí temptación».

E díxole jurando que después que ovo cincuenta años nunca le dexara la temptación «de noche nin de día. En tanto que creyendo que Dios me avía desanparado, escogí más morir que vivir así torpemente. E fue e púseme desnudo en una cueva de leones e estude allí por todo el día por que veniessen e me comiessen. E desque venían las bestias, desde la cabeça fasta los pies me adoravan e todo me lamían, e ívanse. E pensando que Dios me avía perdonado, tornéme a mi celda. E dende a pocos días vínome la temptación mucho más fuerte, en manera que estude a tiempo de blasfemar. E quando me bolví, el diablo, en figura de moça negra que yo oviera en mi mancebía algunas vezes, asentósse sobre mis inojos e movióme muy grand temptación de luxuria, onde yo, con grand saña, dile grandes bofetadas en las narizes e en las maxillas, e luego la fantasma desaparesció. Mas acerca de dos años, me quedó el fedor en las manos. E estando ya para desesperar de la salut de mi ánima e en mucho lloro, oí una voz que me dixo: 'Pachón, yo dexé que te veniesse esta temptación por que non te ensalces en sobervia e que oviesses temor e conosciesses tu enfermedat e fraqueza e confiasses en solo Dios, ca Él abaxa a los que confían en sí mesmos e ayuda a los que pelean contra las temptaciones'. E desde allí, por gracia de Dios, beví en paz». 


\section{CrAlfX págs. 7-8}

Leyenda del infante D. Enrique en Túnez.

En el seteno año del regnado del rey don Alfonso, que fue en la era de mill e docientos e noventa e siete años, e andaba el año de la nascencia de Jesucristo en mill e docientos e cincuenta e nueve años, el rey don Alfonso estava en Sevilla e el infante don Enrique estava en Lebrija, e dijeron al rey que el infante don Enrique tenia fecho fablas con algunos ricos homes e caballeros del reino en su deservicio. E por esto el rey mandó a don Nuño que lo fuese a prender. E don Nuño salió de Sevilla, e llegando cerca de Lebrija, don Enrique sopo como don Nuño iba a lo prender e salió a él al campo e ovieron pelea de consuno, e acaesció que amos a dos se firieron, e don Nuño fué ferido en el rostro e estúvose por vencer, ca don Enrique e los suyos peleaban muy fuerte. E a don Nuño cresció grand compaña que le envió el rey, e don Enrique e los suyos ovieron a dejar el campo e tornar á Lebrija; e en esta noche partió dende e fue al Puerto de Santa María. E como quier que el lugar non era aún poblado, estavan ý navíos, e entró en uno dellos e fue por la mar á Cáliz. E falló ý una nave que iva a Valencia, e fue en ella al regno de Aragón por cuanto estonces era vivo el rey don Jaimes, suegro del rey don Alfonso; e e1 rey don Jaimes non lo quiso ý tener contra voluntad del rey don Alfonso, e mandóle que se fuese del regno. E por esto el infante don Enrique pidióle que le diese navíos en que fuese e que pasaría la mar, e el rey don Jaimes tóvolo por bien. E desde Barcelona pasó á Túnez, e el rey de Túnez acogióle muy bien porque sopo que era fijo de rey, e dióle mucho de lo suyo, e moró con él ý cuatro años. E en las peleas e contiendas que este rey de Túnez avía con los moros sus vecinos, este infante don Enrique servíale muy bien e avía muy grand fama e ardideza e grand prez de caballería en todas aquellas tierras. E los moros del regno de Túnez fablaron con el rey e dijéronle que aquel infante cobraba mucho los corazones de las gentes de la tierra, e los contrarios, que le avían mucho miedo e que traían muchas gentes de cristianos, e destas cosas tales que se podía seguir muy grand daño e muy grand deservicio á aquel rey, e que era menester que lo enviase del regno, ca él e las sus gentes eran para amparar e defender la su tierra sin él, e la defendieron otra vez. E como quier que al rey de Túnez pesaba por esto que le decían del infante, pero non pudo excusar de creer a los suyos, e cataron manera para lo enviar del regno. E recelaron que si el rey ge lo dijese o ge lo mandase decir, que pornía algund alboroto en el regno o se iría para sus contraríos con aquellas gentes que allí tenía, e por esto que era bien de tener manera como lo matasen. E porque non fallaron razón para lo facer, temiéndose de los suyos, que eran muy fuertes 
caballeros, acordaron que llamase el rey al infante a fabla en un corral en que metiesen ý con él dos leones que estaban en un apartamiento, e aquellos que lo matarían. E el consejo avido, pusiéronlo por obra; e luego el rey mandó llamar a don Enrique a la fabla, e entró dentro en el corral do era consejado que entrase. E todas las gentes suyas que lo guardaban fincaron en otras casas por do iban entrando, que eran muy redradas dende. E el infante, estando allí con el rey, díjole el rey que le esperase allí e que luego vernía allí a él; e salió el rey de aquel lugar del corral, e por la otra parte salieron los dos leones a fiucia que lo matarían. E don Enrique sacó la espada que él traía consigo, que la non partía de sí, e tornó contra ellos, e los leones non fueron a él; e don Enrique fue a la puerta e salió del corral. E entre tanto que él estaba en esto, los moros prendieron todas las gentes de don Enrique. E desque él fue salido del corral, el Rey non quiso que lo matasen nin le quiso ver, e envióle a mandar que se fuese del regno. E don Enrique pidióle que le mandase soltar sus compañas, e el rey mandó que soltasen muy pocos dellos, solamente los que avían pasado con él, ca de los cristianos que eran primero e le servían no soltaron ninguno. E don Enrique fuese para Roma a la guerra [...].

\section{I.3.a Cambio de personaje conlleva el cambio de un elemento que introduce cambio de identidad: Un judio escucha una conversación entre diablos}

\section{EXM 29}

Enseñaron nuestros maestros: Érase un gentil y un judío que iban de camino; dijo el gentil al judío: «Mi religión es mejor que la tuya». Le respondió el judío: «No, la mía es mejor que la tuya, pues está dicho: ¿Cuál es la gran nación que posee estatutos y decretos tan justos como toda esta ley? [De 4:8]». Dijo el gentil: «Preguntemos a alguien. Si dice que mi religión es mejor que la tuya, me quedo con tu dinero y si dice que tu religión es mejor que la mía, te quedas tú con mi dinero». Dijo el judío: «Acepto la apuesta».

Y continuaron juntos. Les salió al encuentro Satán bajo la apariencia de un viejo. Le preguntaron y les dijo: «La religión del gentil es mejor». Siguieron andando. Les volvió a salir al encuentro Satán bajo la apariencia de un joven. Le preguntaron y les contestó: «La religión del gentil es mejor». Y siguieron andando. Se disfrazó otra vez el diablo de viejo. Le preguntaron y respondió: «La religión del gentil es la mejor». 
Y así el gentil se quedo con el dinero del israelita, que se marchó cariacontecido y pernoctó en un lugar en ruinas. Hacia las tres de la madrugada oyó a unos demonios que hablaban entre sí; dos le preguntaban a otro: «¿Dónde has estado hoy?». Les contestó: «He encontrado a un judío y un arameo y me he burlado de ellos testificando a favor del gentil». Preguntaron al segundo: «Y tú, ¿dónde has estado?» Respondió: «Estuve impidiendo parir a la hija del César, que ya lleva siete días con dolores de parto; pero si cogieran hojas del árbol que está cerca de sus letrinas y le frotaran con ellas la nariz, al momento pariría».

Preguntaron al tercero: «Y tú, ¿dónde estuviste?». Les respondió: «Estuve cegando la fuente de tal ciudad; pero si cogieran un buey negro y lo mataran, se arreglaría».

Conservó el judío esas palabras en su corazón.

Por la mañana se dirigió a la ciudad del César, y encontró a su hija con dificultades para parir. Dijo a los que allí estaban: «Coged hojas del árbol que hay junto a las letrinas y frotadle la nariz». Las cogieron, le frotaron la nariz, y al momento parió. El rey le dio mucho dinero, pues no tenía más hijos que esta.

Después se dirigió a la ciudad cuyas aguas estaban cegadas y dijo a los habitantes: «Coged un toro negro, matadlo junto a la fuente y la fuente manará». Lo cogieron, lo mataron y la fuente volvió a manar. Los habitantes de la ciudad le dieron mucho dinero.

A la mañana siguiente se encontró con el gentil que le había ganado el dinero quien, muy sorprendido, le pregunto: «¿No te quité todo el dinero?, ¿de dónde has obtenido esta riqueza?». [El judío] le contó todo lo ocurrido. Dijo [el gentil]: «Iré yo también y les preguntaré desde aquellas ruinas». Se fue y pernoctó en aquel lugar. Vinieron los tres demonios y le mataron, pues está dicho: El justo de la angustia será librado y el malvado le reemplazará [Pr 11:8].

\section{$\operatorname{ExABC} 92$ (21)}

CRUCIS VIRTUS ECIAM APUD INFIDELES MAXIMA CONPROBATUR: La virtud de la cruz salva a los cristianos / e algunas veces a los paganos.

[1.1] Cuenta Sant Gregorio en el tercero libro de los Diálogos que avía un obispo en la cibdat de Fundis que avía nonbre Andrés, e estava con él una monja. E el diablo, que es enemigo, púsole en la voluntad de pensar en su lecho en maldat de pecado. E acaesció que un día un judío iva a Roma e 
llegó tarde, e deque non falló onde aver posada, entró en un templo de un dios que llamavan Apolo para quedar allí aquella noche. E comoquier que él non creía la cruz, por temor, signósse con la señal de la cruz, e a la medianoche, estando despierto, vio muy gran conpaña de spíritus malignos, que estavan en servicio de uno que era mayor dellos assentado en medio; e començó a demandar a cada uno de aquellos que le servían qué es lo que avía fecho e fazer inquisición sobre ello.

[2.] E la manera desta inquisición brevemente la dize Sant Gregorio, mas puédese saber más largamente por un enxenplo que se leye en la Vida de los Santos Padres: que dizen que un ombre, entrando en el templo de los ídolos, vio a Sathanás assentado e su cavallería acerca dél en derredor. E vino uno de los spíritus malignos e adorólo, al [qual] dixo: «¿Onde vienes?». E respondió: «Estude en aquella provincia e levanté muchas guerras e muchas turbaciones e fize que se matassen muchos ombres, e vengo a te lo fazer saber». E preguntóle: «¿En quánto tienpo lo feziste?» E respondió: «En treinta días». E dixo Satanás: «¿Por qué en tan gran tienpo feziste tan poco?». E mandó a los que allí estavan que [1]e diessen muchos açotes.

E vino el segundo e adorólo e dixo: «Señor, yo era en la mar e levanté muchas tenpestades e fize fundirse muchas naos en que morieron muchos ombres». E preguntóle: «¿En quántos días lo feziste?». E dixo: «En veinte». E mandólo açotar como al otro.

El tercero vino e dixo: «Yo levanté peleas e contiendas en unas bodas en que morieron muchos ombres e maté al esposado, e véngotelo a dezir». E dixo: «¿En quánto tienpo lo feziste?». E respondió: «En diez días». E díxole: «¿Non feziste más en tanto tiempo?». E mandóle açotar.

E otro vino e dixo: "Yo moré en el desierto por quarenta años e trabajé acerca de un monje e a la fin apenas le traxe a consentir a caer en tenptación de la carne». E quando esto oyó Satanás, levantósse de la silla e diole paz, e tiró la corona de su cabeça e púsogela a él e fízole asentar consigo. E dixo: «iGrande e fuerte cosa feziste! Más trabajaste que todos».

[1.2] E tal podría ser la manera que dezía Sant Gregorio del jodío. E después que todos los spíritus dixieron lo que avían fecho, levantóse uno en medio e dixo en quánta tenptación de la carne avía traído al coraçón de aquel obispo Andrés por aquella monja: e desde ayer en la tarde fasta aquella hora le induziera a dar una palmada en las espaldas. E el spíritu mayor mandóle que acabasse lo que avía començado e avería fecho mayor cosa que todos los otros. E mandóle que sopiesse quién era aquel que yazía en el templo. 
E el judío ovo muy grand miedo. E los spíritus que fueron a él falláronlo señalado de la señal de la cruz, e espantados, dieron grandes bozes: «iGuay! ¡Guay! ¡Vaso vazío, mas signado!». E a aquesta boz luego desaparesció aquella conpaña de los spíritus malignos. E luego aquel judío fue para aquel obispo e contóle todas estas cosas por orden; el qual, oyendo esto, ovo grand dolor e arrepentimiento e mandó echar todas las mugieres de su casa e vezindat. E bauptizó al jodío.

\section{EspLeg 137}

E aun dize San Gregorio en el tercero libro del Diálogo que como un judío fuese camino e llegase de noche a un tenplo del ídolo de Apolo e oviese gran temor por ser tal el lugar, signóse de la sennal de la cruz aunque non avía la fe de Jhesuchristo nuestro Salvador. E acerca de la medianoche vinieron munchos diablos con su príncipe e fazían su ayuntamiento, e dizía cada uno a su príncipe los engannos que avían fecho. E uno dellos dixo que avía traído al varón onorable Andrés, obispo de la cibdad de Fundanes, a tan grand danno e peligro de la su castidad, que avía dado a una muger que estava en su casa con la mano en las espaldas, en sennal de amor carnal. E oyendo esto el príncipe de maldad, mostró gran placer además e començóle a amonestar que trabajase varonilmente por engannar al varón santo e dar fin a lo que avía començado. E dichas estas cosas, mandó a los espiritus malos que allí estavan que catasen si avía allí alguno que oviese oído los secretos del su ayuntamiento. E yendo los espíritus malos a buscar, segund les fuere mandado, fallaron al judío, que estava signado de la cruz de Jhesuchristo, e començaron a dar grandes bozes e dezir: «¡Guay, guay, guay del vaso vazío e santiguado!».

E partiendo de allí otro día el judío, fuese para el santo obispo e díxole lo que avía oído e vido; e apartólo del mal que avía pensado de fazer, e él rescibió el bautismo de Jhesuchristo con fe.

E de aquí es lo que es escripto a los IX capítulos de Ezechiel: Non matades al que vierédes que trae sobre sí la $T$ [Ez 9:4]. E la T es una letra que es fecha a manera de cruz, en figura que la cruz del Sennor libra al ome e lo defiende de la muerte. 


\section{I.4.a Mismos personajes pero cambio de un elemento que introduce cambio de identidad: El medio amigo ${ }^{65}$}

\section{EXM 360}

Un padre le pidió a su hijo que intentara conseguirse un verdadero amigo. El hijo contestó que ya tenía cien. El padre le respondió que él tenía sólo uno o quizás medio, y que pondría a los amigos de su hijo a prueba. Mató una oveja, la puso en un saco chorreando sangre y le pidió a su hijo que le ayudara a cargársela a hombros. Llamó a la puerta de uno de los amigos de su hijo y le dijo que éste había matado involuntariamente a uno de sus enemigos y le rogó que lo escondiera. El amigo lo rechazó tajantemente y lo mismo hicieron los demás. El padre lo llevó entonces a su propio amigo que inmediatamente lo acogió y dijo que por la noche cavarían una tumba en su jardín para así borrar todas las pistas. El hijo reconoció entonces la verdad del consejo de su padre

\section{DCler 1}

\section{El medio amigo.}

Un árabe, a punto de morir, llamó a su hijo y le dijo: «Dime, hijo mío, cuántos amigos adquiriste en tu vida». El hijo respondió: «Creo que adquirí cien amigos». Díjole el padre: «Dice el filósofo: 'No alabes al amigo hasta que lo hayas probado'. Yo nací antes que tú y apenas puede decirse que logré la mitad de uno. Tú, ¿cómo te hiciste con cien? Ve a probarlos, para saber si alguno entre todos es tu amigo verdadero». Dijo el hijo: «¿Cómo me aconsejas probarlos?» Dice el padre: «Pon en un saco un ternero muerto y partido en pedazos, de modo que el saco quede sucio de sangre por fuera, y cuando llegues a casa del amigo, dile: 'Querido amigo, maté involuntariamente a un hombre; te suplico que lo entierres en secreto, pues nadie sospechará de ti y en cambio, a mí podrás, así, salvarme».

Hizo el hijo como el padre le mandó. El primer amigo al que acudió le dijo: «Llévate ese muerto a cuestas; puesto que hiciste un mal, sufre el castigo. No entrarás en mi casa». Habiendo hecho lo mismo con cada uno de sus amigos,

\footnotetext{
${ }^{65}$ De acuerdo con el criterio expresado supra, n. 46, no transcribimos el texto de las muy conocidas versiones de Zifar (Ms. M, fols. 8-10) y Lucanor (48: Lo que sucedió a uno que provava a sus amigos), disponibles ambas en colecciones universitarias de amplia difusión; cf. infra, Bibliografía.
} 
obtuvo de todos la misma respuesta. Volviendo junto a su padre, le contó cómo habían ido las cosas. El padre le dijo: «Te sucede lo mismo que dijo el filósofo: 'Muchos son los amigos, mientras lo son de nombre, pero pocos lo son en la necesidad'. Vete a casa de ese medio amigo que yo tengo y mira a ver qué te dice». El hijo fue y díjole lo mismo que había dicho a otros. Y él contestó: «Entra en mi casa. No es éste un secreto que deba propagarse entre los vecinos». Y haciendo salir a su mujer con toda su familia, cavó una sepultura. Una vez que estuvo preparada, díjole aquel la verdad, tal como era, y le dio las gracias. Luego refirió a su padre lo ocurrido. Y el padre dijo: «A propósito de amigos como ese dice el filósofo: 'El verdadero amigo es el que ayuda cuando el mundo te 'abandona'».

\section{$\operatorname{ExABC} 18$}

AMICUS VERUS EST QUI CUM SECULUM DEFECIT TUNC SUCURRIT: El amigo es de alabar / que al tiempo de la priesa quiere ayudar.

Un hombre de Arabia, estando a la muerte, llamó a su fijo e díxole: «¿Quántos amigos tienes?». E el fijo respondió e dixo: «Segund creo, tengo ciento». E dixo el padre: «Cata que el philósofo dixo: 'Non alabes al amigo fasta que lo ayas provado'. E yo primero nascí que tú e apenas pude ganar la meitad de un amigo; e pues assí es, ¿cómo tú ganaste ciento? Ve agora e pruévalos todos, porque conoscas si alguno de todos ellos te hes acabado amigo». E dixo el fijo: «¿Cómo me consejas que lo faga?». Dixo el padre: «Toma un bezerro e mátalo e fázelo pieças e mételo en un saco en manera que de fuera paresca sangre, e quando fueres a tu amigo, dile assí: 'Amigo muy amado, trago aquí un ombre que maté. Ruégote que lo entierres secretamente en tu casa, que ninguno non averá sospecha de ti, e assí me podrás salvar».

El fijo lo fizo como le mandó el padre. El primero amigo a que fue díxole: «Liévate tu muerto a cuestas, e como feziste el mal, párate a la pena. En mi casa non entrarás». E assí fue por todos los otros amigos e todos le dieron aquella misma respuesta.

E tornósse para su padre e díxole lo que feziera. E dixo el padre: «A ti acaesció segund dixo el philósofo: 'Muchos son llamados amigos e al tiempo de la necesidat e de la priessa son pocos'. E ve agora al mi medio amigo e verás lo que te dirá».

E fue a él e díxole: «Entra acá en mi casa, por que los vezinos non entiendan este secreto». E enbió luego a la mugier con toda su conpaña fuera de casa e cavó una sepultura. E quando el mancebo vio lo que había fecho e la buena voluntad de aquel medio amigo de su padre, descobrióle el negocio cómo era, dándole muchas gracias. 
E dende tornósse a su padre e contóle lo que le feziera. E díxole el padre: «Por tal amigo dice el philósofo: 'Aquel es verdadero amigo que te ayuda quando el mundo te fallesce».

\section{EspLeg 49}

Recuenta Per Alfonso que un viejo de Arabia preguntó a su fijo quántos amigos avía e respondiole que avía mas de ciento e díxole el padre: «Bien libraste, ca yo non pude aver en toda mi vida mas de uno; mas por que prueves a tu amigo, toma un bezero muerto e mételo en un costal, e ve a él de noche, e dile que traes ome que mataste e ruégale que te lo encele e te ayude a enterrar el muerto». E fízolo el fijo todo por orden; e oyendo aquel su amigo lo que traía dixo: «¿Tú mataste el ome e tráeslo a mi casa por que yo sea enforcado por lo que tú feziste? Liévalo muy apriesa; ca del mi aver te ayudaré, mas en este fecho non te ayudaré en ninguna manera». Así que tornóse el fijo al padre e recontóle todas las cosas segund le acaecieron; e díxole el padre: «Fijo, ve a mi medio amigo que te aconseje en este fecho». E fue el fijo e recontó al medio amigo del padre lo que dixera primero al su amigo, e respodióle e dixole: «Fijo, bien lo faremos». E enbió toda la conpanna de casa e fizo una fuesa so su lecho en la qual enterró al muerto. E esto fecho, contóle el fijo la verdat de la cosa, faziéndole gracias por la entera amistança; e tornó al padre e contóle todas las cosas cómo fueran fechas.

E al tal amigo es dicho en el nono capítulo del Eclesiástico: Non desanpares al amigo antiguo, ca por natura el nueuo non será semejable [Eclo 9:10]. E dize Tulio: «Nunca enojes a los amigos viejos por la novedad de los siguientes; ca non debemos usar de los amigos como de las flores, que solamente son apazibles mientras son rezientes».

\section{II.1.a Relatos sin expresión directa de identidad; esta se asocia con co- mentarios o moralizaciones añadidos: El falso heredero.}

\section{$S \check{S} 5$}

Había un comerciante de los mejores, más famosos y más ricos, que tenía solamente un hijo. Cuando creció el muchacho le dijo a su padre: «Déjame partir, pues quiero viajar por tierras lejanas para comerciar y ver países y regiones, eruditos y sabios de cuyas enseñanzas y conocimientos quiero aprender y tomar de su inteligencia y sabiduría». El padre aceptó porque era su único hijo y tenía plata y oro. Le compró un barco y le entregó una gran fortuna, y le dejó partir [...]. 
El hombre se quedó en casa con su criado, hijo de su sirvienta, al que cuidaba como a la niña de sus ojos, y lo colocó en el lugar de su hijo, porque era el siervo que tenía éxito en todas sus empresas y era diligente en todas sus necesidades. Al cabo de algún tiempo le sobrevino al dueño de la casa un dolor en el corazón, de modo que expiró y murió de repente sin lograr declarar ni ordenar nada. El criado tomó todo lo que tenía y se adueñó de todo el fruto de su trabajo [Qo 2:9]. En la ciudad nadie sabía si era su criado o su hijo, porque cuando estaba vivo le había dado poder sobre toda su hacienda y fortuna. Unos diez años después de la muerte de aquel hombre, volvió el joven, su hijo, con el barco lleno de mercancías y productos de lo más selectos. Sucedió que cuando pasaba cerca de su ciudad pareció que el barco iba a zozobrar, y lanzaron al mar todos los objetos y mercancías [Jon 1:4] que habían adquirido y remaron para llegar a tierra, mas no lo consiguieron. El joven llegó nadando a tierra y, afligido y sin nada, se encaminó hacia la casa de su padre para cubrir su desnudez, y cuando lo encontró allí el criado lo insultó y ultrajó diciendo: «¿Qué tienes tú aquí, y a quién tienes aquí?». Lo golpeó y lo echó de su casa y lo despojó de su heredad.

Se dirigió el joven a casa del juez, e iba llorando mientras caminaba, y dijo al juez: «Mi siervo me ha hecho esto y esto», y le contó todo lo que le había sucedido: cómo le había golpeado y expulsado de su casa el criado al que su padre había educado y elevado.

El juez mandó llamar al criado, mientras el joven seguía llorando intensamente. Compareció el criado, y cuando el juez observó su rostro, le pareció un hombre vil. Le preguntó: «¿Es verdad que el hombre cuya propiedad y su hacienda tomaste era tu padre? Porque este dice que tú eras criado de la casa y no tienes derecho a la herencia, a no ser por la ley de la fuerza, y que la has obtenido con la traición y la impostura».

Respondió el criado diciendo: «Mi señor, verdaderamente él era mi padre y yo salí de sus lomos. Por eso me dejó su propiedad y todos sus bienes y objetos preciosos. Mi corazón se lamenta por él, porque desde mi infancia me crió como un padre».

El juez le dijo: «Trae tus testigos para justificar tus palabras y todo lo que tienes en tu poder». Dijo él: «Por favor, mi señor, que presente sus testigos este impostor cuyos ojos astutamente lloran, porque al demandante corresponde aportar las pruebas».

Buscaron ambos testigos, pero no los hallaron, y volvieron ante el juez para decirle: «Tú, nuestro señor, resolverás nuestro pleito; como no tenemos testigos, tú eres nuestra esperanza». Dijo el juez: «¿Hay alguien aquí que conozca su 
sepultura?». Respondió el criado: «Yo lo sé, pues yo mismo lo enterré como entierra el hijo a su padre». Dijo el juez a sus sirvientes: «Venid conmigo a ese horrible lugar y echadlo de su tumba como un brote despreciable, y traedme sus huesos y los quemaré, porque no hizo testamento en su casa, ni dijo para quién sería su herencia, dejando detrás suyo riñas y pleitos, muchas disputas y reclamaciones». Dijo el criado: «Yo iré, según las palabras de mi señor y sus órdenes, y les mostraré su sepultura, pues una sentencia acertada has pronunciado y como un ángel de Dios has hablado».

Mas cuando oyó el hijo el asunto de la cremación, gritó con el alma indignada y furiosa, y dijo: « $¡$ Mi señor, que coja el criado toda la herencia de mi padre, todo su honor y riqueza, pero que mi padre no sea arrojado de su tumba!».

Entonces el juez contestó: «He aquí que yo te entrego la herencia de tu padre, toda su riqueza y fortuna, pues en verdad éste es su criado y tú eres su hijo. En cuanto al siervo que se envalentonó sin avergonzarse, lo tomarás como esclavo para siempre».

Marchó el joven a la casa de sus padres y el criado fue azotado. Él tomó de manos del criado riquezas, bienes y honores.

\section{$\operatorname{ExABC} 174$ (103)}

FILIUS NATURALITER NOSCIT PATREM: El fijo naturalmente / conosce a su padre ciertamente.

Para catar reverencia a los padres la natura lo muestra, según un e[n]xemplo que dizen que un buen ombre tenía una mugier que fazía adulterio e tenía tres fijos. E él, maltrayéndola del pecado e dándole mala vida, e ella le dixo que sienpre sería triste porque el uno de aquellos tres fijos hera suyo, los otros dos de adulterio, e non le quisso dezir quál era suyo por que por amor de aquel feziesse bien a los otros. E el buen ombre, quando ovo de morir, fizo heredero a su fijo de todos sus bienes; e cada uno dezía ser heredero legítimo, por lo qual ovieron de venir a juizio. E el joez dio sentencia que cada uno dellos lançasse una saeta al cuerpo de su padre muerto; quien mejor lançasse en el cuerpo en medio, esse oviesse la heredat. E los dos lançaron fuertemente sus saetas e el que era verdadero fijo dixo que nunca lançaría contra su padre, e si alguno de allí adelante lançasse, que él ge lo demandaría malamente. Estonce el joez judgó que aquel era fijo verdadero e eredero, ca la natura le mostró fazer aquello que devía fazer a su padre. 


\section{GesRoman 45:}

Sobre cómo sólo los buenos entrarán en el reino de los cielos.

Había un rey nobilísimo, sabio y rico, que tuvo una esposa muy amada, la cual, olvidándose del amor debido a su esposo, engendró en una relación extramatrimonial tres hijos ilegítimos que siempre estaban en actitud de rebeldía contra el rey y en nada eran semejantes a él. Después concibió legítimamente del rey un cuarto hijo, lo parió y lo crió. Sucedió, sin embargo, que, cerrado el círculo de sus días, murió el rey y su cuerpo regio fue enterrado en un sarcófago. Después de su muerte, los cuatro hijos antes mencionados comenzaron a rivalizar por el dominio del reino. Finalmente, acordaban entre sí acudir a un caballero veterano de la corte del difunto rey, en otro tiempo consejero especial, y someterse simple y llanamente a su veredicto. Y así se hizo. El caballero, después de escuchados con paciencia, dijo: «Escuchad mi consejo, pues si lo cumplís todo irá bien. Conviene que extraigáis del sarcófago el cuerpo del difunto rey y aquel de vosotros que tenga el arco preparado con la flecha y atraviese más certeramente su cuerpo, obtendrá el reino». Les pareció bien el consejo, es decir, desenterrar al padre de su tumba y atarlo a un árbol. El primero disparó su flecha y, después de atravesar la mano derecha del rey, se proclamaba, como consecuencia de ello, dueño del reino como único heredero. El segundo, en cambio, con un disparo más certero atravesó su rostro con indisimulada alegría, por lo que se atribuía el reino con total convencimiento. El tercero, por su parte, atravesó con la flecha su corazón, por lo que juzgaba sin lugar a la menor duda que sería con toda seguridad el dueño del reino con preferencia a sus hermanos. El cuarto, al acercarse al cuerpo de su padre, rompió a llorar y con voz lastimera dijo: «¡Ay de mí, padre mío!, veo tu cuerpo herido de semejante manera por tus propios hijos. Lejos de mí herir el cuerpo de mi padre, vivo o muerto». Al oír estas palabras, los príncipes del reino, acompañados por todo el pueblo, levantaron en alto al hijo pequeño y lo colocaron en el trono del padre, como verdadero heredero y señor del reino. Los otros tres, en cambio, fueron privados de toda dignidad y riquezas y expulsados de todo el reino.

Moralización:

Queridísimos, este rey sabio, noble y rico, es el Rey de Reyes y Señor de Señores. No parece incongruente señalar que unió a sí con especial privilegio a la criatura del género humano, como si se tratase de una esposa predilecta; pero ésta, como si se tratase de una adúltera, engendró tres hijos, fruto de relaciones mantenidas con otros dioses, a saber, los paganos, los judíos y los heréticos. El primero de ellos hirió la mano del rey cuando rechazó la doctrina de Cristo, que está sentado a la derecha del Padre, causando la muerte a los siervos enviados 
por Dios con diversas heridas. El segundo hijo putativo asaeteó verdaderamente al rey de reyes cuando los judíos decían: «Venid, golpeémoslo en la lengua», mientras apagaban su sed con hiel mezclada con vinagre. El tercer hijo, el más pérfido, no deja de atravesar con un dardo envenenado el corazón del sumo rey cada vez que los heréticos persiguen a los fieles, pues todo su corazón y alma tienen como objetivo lacerar a su dueño con los dardos de la perversa doctrina, de donde el Salmista: Afilaron sus lenguas como serpientes, etc. [Vg Sal 139:4] Y de nuevo: Colocaron sus flechas en la aljaba [Vg Sal 10:3]. El cuarto hijo, el que siente dolor y no quiere lanzar su flechas, es el buen cristiano que siente un gran temor de Dios y se duele por los pecados ajenos y bajo ningún pretexto quiere ofender a Dios con el pecado y, si le ofende, está dispuesto a cumplir la penitencia; tal será exaltado al reino eterno el día del Juicio. 


\section{Bibliografía de fuentes primarias}

Antigüedades: Josephus, Jewish Antiquities, trad. y ed. R. Marcus, 9 vols. (London 1930 y ss.).

Cantigas: Alfonso X el Sabio, Cantigas de Santa María, ed. W. Mettman (Madrid 1986).

Castigos: Castigos del Rey don Sancho IV, ed. H. Ó. Bizzarri (Frankfurt-Madrid 2001).

CrAlfX: Crónica de Don Alfonso X, en Crónicas de los Reyes de Castilla, ed. C. Rosell, I (Madrid 1953; BAE, LXVI).

DCler: Pedro Alfonso, Disciplina Clericalis, trad. y ed. E. Ducay y $\mathrm{M}^{\mathrm{a}} \mathrm{J}$. Lacarra (Zaragoza 1980).

DDM: «La declaración de los Diez Mandamientos en su versión judeoespañola», ed. A. Alba y C. Sainz de la Maza, Bulletin Hispanique 103 (2001), págs. 369-402.

Esopete/Fábulas coletas (Sección tomada de DCler incorporada al Esopete ystoriado): Esopete Ystoriado (Toulouse 1488), ed. V. A. Burrus y H. Goldberg (Madison 1990).

EspLeg: El Espéculo de los Legos. Texto inédito del siglo XV, ed. J. M. Mohedano (Madrid 1951).

ExABC: Clemente Sánchez de Vercial, Libro de los Exenplos por ABC, ed. J. E. Keller (Madrid 1961).

EXM: Moses Gaster, The Exempla of the Rabbis (New York 1968).

GRom: Gesta Romanorum. Exempla europeos del siglo XIV, trad. y ed. J. Lozano y V. de la Torre (Madrid 2004).

LCMP: H. O. Bizzarri y C. Sainz de la Maza, «El Libro de confesión de Medina de Pomar [I a IV]», Dicenda 11 (1993), págs. 35-36; 12 (1994), págs. 1936; 13 (1995), págs. 25-38; y 14 (1996), págs. 47-58.

LegAu: Santiago de la Vorágine, La Leyenda Dorada, trad. J. M. Macías (Madrid 1982).

Lucanor: Don Juan Manuel, El conde Lucanor, ed. G. Serés, intr. G. Orduna (Barcelona 1994). 
MDM: El Midrás de los Diez Mandamientos. El libro precioso de salvación, trad. y ed. A. Alba (Valencia 1990), págs. 25-99.

MhG: Midrash ha-Gadol, ed. M. Margoliouth (Jerusalem 1975).

Milagros: G. de Berceo, Los milagros de Nuestra Señora, ed. B. Dutton (London 1980).

Mtanh: Midrasch Tanchuma, ed. S. Buber (Wilna 1885).

Recull: Arnau de Lieja, Recull d'exemples $i$ miracles ordenat per alfabet (Barcelona 2004).

ShMa: Sefer ha-Ma'asiyot: Libro precioso de salvación, en A. Alba (ed.), El Midrás de los Diez. Mandamientos, págs. 101-283.

Š̆: Yosef Ibn Zabarra, Libro de los entretenimientos [Sefer Ša 'ašu im], ed. M. Forteza (Madrid 1983).

TB: The Babylonian Talmud, 20 vols. (London 1952).

VYeh: Selomoh Ibn Verga, La Vara de Yehudah (Sefer Sebet Yehudah), trad. y ed. M. J. Cano (Barcelona 1991).

Zifar: Libro del cavallero Zifar, ed. J. González Muela (Madrid 1982).

Recibido: 17/12/2009

Aceptado: 30/04/2012 